Hanaa M. Elabbasy' ${ }^{1}$ Samir M. Zidan², Abd El-Aziz S. Fouda ${ }^{2 *}$

${ }^{1}$ Misr higher Institute for Engineering and Technology, Mansoura, Egypt, ${ }^{2}$ Mansoura University, Department chemistry, Faculty of Science, Mansoura-35516, Egypt
Scientific paper

ISSN 0351-9465, E-ISSN 2466-2585

UDC: $620.193 .4: 669.11-026$

doi: $10.5937 /$ zasmat1902129E

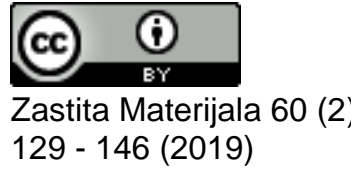

\title{
Inhibitive behavior of ambrosia maritima extract as an eco-friendly corrosion inhibitor for carbon steel in $1 \mathrm{M} \mathrm{HCl}$
}

\begin{abstract}
The inhibition effect of Ambrosia Maritima, which also named after (Damsissa) extract, towards the corrosion of carbon steel in $1 \mathrm{M} \mathrm{HCl}$ solution was investigated utilizing potentiodynamic polarization, electrochemical impedance spectroscopy (EIS) and electrochemical frequency modulation (EFM) methods. The process of adsorption obeyed Langmuir adsorption isotherm. Damsissa extract was found to act as a mixed-type in $1 \mathrm{M} \mathrm{HCl}$. The computed adsorption thermodynamic parameters demonstrated that the adsorption was a spontaneous, endothermic process accompanied by an increase in the entropy. The maximum value of the inhibition approached $92.6 \%$ within the presence of 300 ppm Damsissa extract utilizing Tafel polarization procedure. The results obtained from the various electrochemical processes were in a great agreement. The inhibition of the extract was assumed to occur through the adsorption of active ingredients on the metal surface. Morphology of the surface was analyzed utilizing scanning electron microscopy (SEM), Fourier transforms infrared (FTIR) and atomic force microscopy (AFM) which confirmed the presence of a protective film of extract molecule on carbon steel 1018 surface.
\end{abstract}

Keywords: Ambrosia Maritima (Damsissa), Carbon Steel 1018, HCl, AFM, SEM.

\section{INTRODUCTION}

Carbon steel is one of the iron alloys that greatly utilize in the manufacture of industrial products because it shows excellent, lowtemperature toughness, hydrogen -induced crack and fracture resistances and a good weldability. Aqueous solutions of acids are utilized, by wide shape, in industries for pickling, acid cleaning of boilers, descaling, and oil well acidizing [1-8]. The main problem concerning carbon steel applications is its relatively low corrosion resistance in acidic solutions, especially in hydrochloric and sulfuric acid solutions. A significant way of keeping carbon steel against deterioration resulting from corrosion is by the utilize of inhibitors. Plant extracts are considered to be good corrosion inhibitors due to they are renewable, facilely obtainable, environmentally safe, and its cost is little [9-14].

\footnotetext{
*Corresponding author: A. S. Fouda

Email: asfouda@hotmail.com

Paper received: 08. 12. 2018.

Paper accepted: 12. 01. 2019.

Paper is available on the website: www.idk.org.rs/journal
}

Heterocyclic components of extracts (alkaloids, flavonoids, carbohydrates, and proteins) include nitrogen, sulfur or oxygen atoms, and include double bonds in the aromatic rings, that are the senior adsorption positions [15-17]. Ambrosia Maritima, L. (Damsissa) family Compositae (Asteraceae) and widely grown in Egypt, especially in Sinai [18]. Investigation of corrosion inhibitory influence of Ambrosia Maritime, $L$ extract on carbon steel type 1018 in $1 \mathrm{M} \mathrm{HCl}$ solutions, through several techniques, is the aim of this study. Several authors tried to employ plant extracts as green corrosion inhibitors [19-28].

\section{EXPERIMENTAL MEASUREMENTS}

\subsection{Plant Preparation Method}

Initially, the freshly Damssisa parts were taken to dry, granulated to powder and 500 gram of the powder was soaked in distilled water, boiling at $100^{\circ} \mathrm{C}$ and kept it up for $48 \mathrm{~h}$ at room temperature. Then, the extract supernatant was taken away, filtered and placed in two closed bottles with capacity $2 \mathrm{~L}$ as a stock solution from Damssisa extract, this stock has been put away at $4^{\circ} \mathrm{C}$ $[29,30]$. Secondly, for getting different concentrations for work, a one gram equivalent 
from Damssisa stock solution was dissolved in $1 \mathrm{~L}$ distilled water to achieve 1000 ppm solution so that, different concentrations (100, 150, 200, 250 and $300 \mathrm{ppm}$ ) were obtained by the dilution utilizing bi-distilled water.

\subsection{High-Performance Liquid Chromatography (HPLC) Analysis}

The HPLC technique has been done under two (Standard/Official (ISO)) test methods: for Flavonoids and Polyphenolic compounds, respectively [31-33]. 5 grams of the investigated compound were taken and mixed with methanol, centrifuged at $104 \mathrm{rpm}$ for a time $60 \mathrm{sec}$. The output supernatant was then filtered over a 0.2 micrometer Millipore membrane, thus, at that point 1-3 $\mathrm{ml}$ has been assembled in a flask in order to admission into an HPLC align 1200 arrangement supplied with self-sampling injector, solvent degasser, ultraviolet (UV) indicator set at $280 \mathrm{~nm}$, $330 \mathrm{~nm}$ for phenols and flavonoids, respectively and quaternary Hewlett Packard pump (series 1100). The temperature of the column was kept up at $35^{\circ} \mathrm{C}$. Methanol and acetonitrile are the mobile phases utilizing in separation process, at a flux rate equals $1 \mathrm{ml}$ per min.

Table 1. Some chemical structures and molecular formulas, examples of major constituents of HPLC Flavonoids and polyphenolic compounds, which isolated from Damsissa extract

Tabela 1. Neke hemijske strukture i molekularne formule, primeri glavnih sastojaka HPLC Flavonoida $i$ polifenolnih jedinjenja, koji su izolovani iz ekstrakta Damsissa

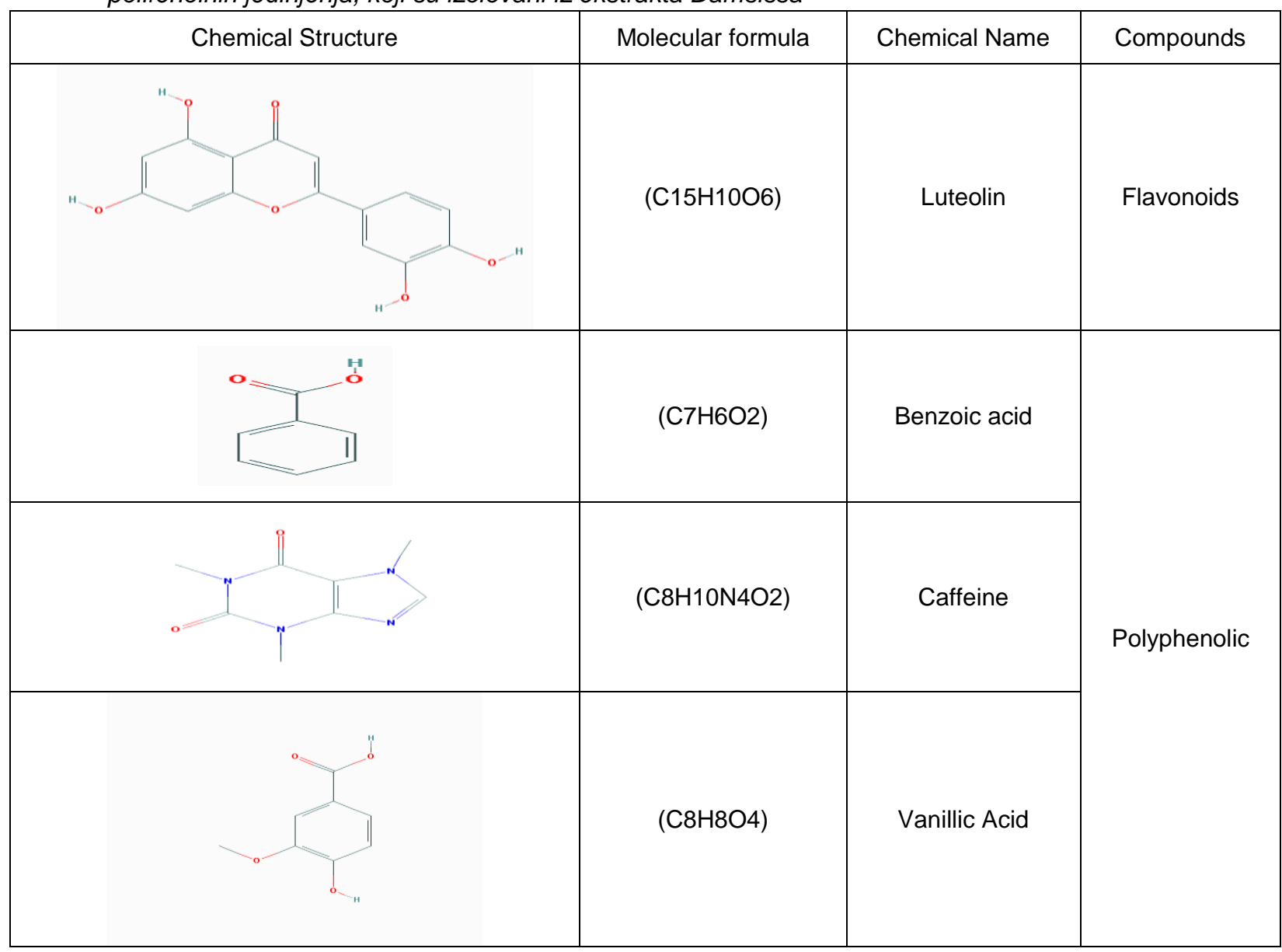

Retention period and peak region were introduced via the information investigation of HP programming. For further study of the behavior of Damsissa extract as an inhibitor towards the corrosion of carbon steel; the isolation of the active constituents from the lyophilized Damsissa extract was made by the aid of both organizations: The National Research Center (NRC) and the Food Technology Research Institute (FTRI) in the
Agricultural Research Center (ARC) located in Dokki, Giza, Cairo [34]. Isolation was made concerning on both flavonoids and polyphenolic compounds (Table 1) from Damsissa extract as follows:

- For Flavonoids, various major HPLC constituents expressing in units $(\mathrm{mg} / 100 \mathrm{~g})$ were; Luteolin-6-arabinose 8-glucose (666.56), Hesperidin (113.46), Acacetin (124.73). Also, 
damsinic acid, neo-ambrosin, and hymenin as well, were previously isolated from the chloroform extract of Damsissa [35, 36]. This flavonoids compounds indicating the presence of mostly more glucose units that giving more existence of oxygen groups that consider to act as an active center in which, it contains an electron donating group causing blocked to the active sites on the carbon steel surface that caused during the redox reaction and therefore, introducing a protective layer from Damsissa under investigation, which as a result, suppresses an aggressive corrosion that caused in the presence of $1 \mathrm{M} \mathrm{HCl}$.

- For the polyphenolic, compounds which expressed in units (ppm) were - E-vanillic (153391), Benzoic (1846.1), Caffeine (74.26), 4-amino benzoic (17.08). These polyphenolic compounds as well, indicated the presence of more oxygen donor atoms in their structure and more electron clouds around benzene rings from benzoic acid and its derivatives, E-vanillic acid, while in caffeine and 4-amino benzoic as another example, in addition, more nitrogen donor atoms appear together with oxygen donor ones which then, assume to block the active sites by sharing its lone pair of electrons with d-orbital of iron on the carbon steel surface [37].

\subsection{Weight loss Method}

This investigation has been performed utilizing carbon steel of type 1018 contains the next composition as weight percent: $\mathrm{Mn} 0.6, \mathrm{Si} 0.003, \mathrm{C}$ $0.2, \mathrm{P} 0.04$ and balance Fe. A $1 \mathrm{M} \mathrm{HCl}$ has been prepared from a reagent bottle of the company name (Scharlau) containing concentrated $\mathrm{HCl}$ $(36.5-38 \%)$ with bi-distilled water, it was Standardized using already prepared Standard $1 \mathrm{M}$ Sodium carbonate $\left(\mathrm{Na}_{2} \mathrm{CO}_{3}\right)$ solution.

Six specimens of carbon Steel 1018 with dimensions $(2 \mathrm{~cm} \times 2 \mathrm{~cm})$ were abraded well using emery paper of grades (up to1200) till the surface be shiny, then, all specimens were washed with acetone to evacuate impurities on metal surface, then washed by bi-distilled water, dried, weighed utilizing (sensitive Digital Balance: (AE-ADAM)- (pw 214)) with four decimal numbers.

One of the specimens has been submerged in $100 \mathrm{ml}$ solution of $1 \mathrm{M} \mathrm{HCl}$ to act as a blank, and the other five specimens were submerged in solutions with different Damssisa extract concentrations $(100,150,200,250,300$ ppm) for a time of $3 \mathrm{~h}$ in a [water bath: (Raypa)- (BAD-6)] which had been previously adjusted at temperature $25^{\circ} \mathrm{C}$, then, all samples were excluded, washed utilizing bi-distilled water, dried gently then weighed accurately. We repeated all of the previous procedure steps at different temperatures $\left(30^{\circ} \mathrm{C}\right.$, $35^{\circ} \mathrm{C}, 40^{\circ} \mathrm{C}, 45^{\circ} \mathrm{C}$ ).

After recording the results in each temperature, the surface coverage, $\theta$, and the inhibition efficiency, \%IE had been calculated utilizing the next equation [38]:

$\% I E=\theta \times 100=\left(W_{\text {inh }}-W_{\text {free }}\right) / W_{\text {free }} \times 100$

Where $W_{\text {inh }}$ and $W_{\text {free }}$ are the weight loss of carbon steel specimens in the presence and absence of Damssisa extract, respectively.

\subsection{Electrochemical Techniques}

The measurements (Tafel polarization, electrochemical impedance spectroscopy, EIS and electrochemical frequency modulation, EFM) occurred in aerated non-stirred $1 \mathrm{M} \mathrm{HCl}$ solution together with concentrations $(100,150,200,250$, $300 \mathrm{ppm}$ ) from Damssisa extract at $25^{\circ} \mathrm{C}$. Solutions were freshly intended from analytical grade chemical reagents utilizing bi-distilled water. For the electrical connection purpose, carbon steel specimen was welded with copper wire, then pasted into glass tubes of convenient diameter for obtaining $(1 \mathrm{~cm} \times 1 \mathrm{~cm})$ of the electrode surface. Before each experiment, the specimens were abraded using different degrees of emery sheet (800 to 1200), washed utilizing acetone, then bidistilled water and lastly prepared to immerse in an electrochemical cell of capacity $100 \mathrm{ml}$ which contain carbon steel 1018 as working electrode, platinum foil as the auxiliary electrode $\left(1 \mathrm{~cm}^{2}\right)$ and saturated calomel electrode (SCE) as reference electrode $[39,40]$.

Tafel polarization was executed utilizing scan rate of $1 \mathrm{mV}$ per second, starting from $-1.7 \mathrm{~V}$ to 0.1 (versus SCE). The open circuit potential as a function of time was evaluated. The needful time for attaining a quasi-stationary value for the opencircuit potential is $30 \mathrm{~min}$. The corrosion current density, $i_{\text {corr }}$ was attained from the junction of the linear part of cathodic and anodic Tafel curves with fixed corrosion potential, $E_{\text {corr }}$ [41]. cathodic $\left(\beta_{c}\right)$ and anodic $\left(\beta_{\mathrm{a}}\right)$ Tafel constants were computed from the linear region of the curves. The corrosion current density $\left(i_{\text {corr }}\right)$ was used in equation (2) for getting the value of the inhibition efficiency (\%IE) as follows :

$\% I E=\theta \times 100=\left[1-\left(i_{\text {corr(inh) }} / i_{\text {corrf(ree })}\right)\right] \times 100$

Where $\mathrm{i}_{\text {corr(inh) }}$ and $\mathrm{i}_{\text {corr(free) }}$ are the current densities in the presence and absence of Damssisa extract, respectively.

EIS estimations were worked out, after 30 minutes of immersion of the working electrode in the $\mathrm{HCl}$ solution, by employing $\mathrm{AC}$ signals have capacity $5 \mathrm{mV}$ peak to peak at the open circuit 
potential in the frequency domain $100 \mathrm{kHz}$ and 0.2 $\mathrm{Hz}$. The estimations were analyzed and explicated utilizing the equivalent circuit. The basic parameters from the Nyquist diagram are the double layer capacity, $\mathrm{C}_{\mathrm{dl}}$, and the charge transfer resistance, $R_{c t}$, that is the high-frequency loop diameter. \% IE and $\theta$ of EIS estimations were counted as follows [42].

$$
\% I E=\theta \times 100=\left[1-\left(R_{c t}^{\circ} / R_{c t}\right)\right] \times 100
$$

Where, $\mathrm{R}_{\mathrm{ct}}^{\circ}, \mathrm{R}_{\mathrm{ct}}$ are the charge transfer resistance in the absence and presence of the extract respectively.

EFM estimates were carried out utilizing $2 \mathrm{~Hz}$ and $5 \mathrm{~Hz}$, but $0.1 \mathrm{~Hz}$ was the base frequency, so the waveform occurs every 1s. The Intermodulation spectra implicate current responses allocated for harmonical and intermodulation current peaks. The bigger peaks were utilized to deduce $\mathrm{i}_{\text {corr }}$, Tafel slopes and the causality factors (CF-2 and CF-3) [43]. The electrochemical estimations were performed utilizing Gamry Potentiostat/ Galvanostat/ ZRA (model PCl 4G 750) with a Gamry system based on ESA 400. A computer with DC 105 programming, EIS 300 programming, EFM140 programming and Echem Analyst 6.33 was utilized to fit and compute the data.

\subsection{Surface Analysis}

In order to perform surface investigations, the carbon steels were exposed to the test solutions for $24 \mathrm{~h}$ at $25^{\circ} \mathrm{C}$. The investigations of surface topography of the pure carbon steel and carbon steel exposed to $1 \mathrm{M} \mathrm{HCl}$ solution without and with the presence of $300 \mathrm{ppm}$ of the Damsissa extract were done utilizing (Scanning Electron Microscope: JOEL 840, Japan) with a magnifying power of (x1500) speed which located in the Faculty of Agriculture, Mansoura university.

The surface morphology of specimens without and with the presence of $300 \mathrm{ppm}$ of the inhibitor was also investigated using (Atomic Force Microscope: SPM 9600, dynamic (Non-contact) mode, Shimadzu) which located in the atomic force lab, Microanalytical center, Faculty of Science, Cairo University. And lastly, specimens surface was analyzed with IR Affinity (Perkin Elmer) spectrophotometer for recording FTIR spectra for Damsissa and Damsissa adsorbed on carbon steel immersed in $1 \mathrm{M} \mathrm{HCl}$ at the central laboratory in the faculty of pharmacy, Mansoura University.

\section{RESULTS AND EXPLANATIONS}

\subsection{Weight Loss Method}

\subsubsection{Adsorption Isotherm}

The study of adsorption isotherm provides some supportive information regarding the corrosion inhibition mechanism. The best isotherm for a particular surface environment absorbent system is chosen by graphically fitting the experimental data to the adsorption equation [44]. After testing several adsorption isotherms including Freundlich, Temkin, Frumkin, BockrisSwinkels, Flory-Huggins and Langmuir, the present data were found to obey Langmuir $2^{\text {nd }}$ equation (Figure 1), thus by plotting Damsissa extract concentrations $\left(\mathrm{C}_{i n h}\right)$ versus $\left(\mathrm{C}_{\mathrm{inh}} / \theta\right)$ and analyzing results, the adsorption constant $\left(\mathrm{k}_{\mathrm{ads}}\right)$ was calculated from the line intercept according to the following Langmuir $2^{\text {nd }}$ equation [45]:

$$
C_{i n h} / \theta=1 / k_{\text {ads }}+C_{i n h}
$$

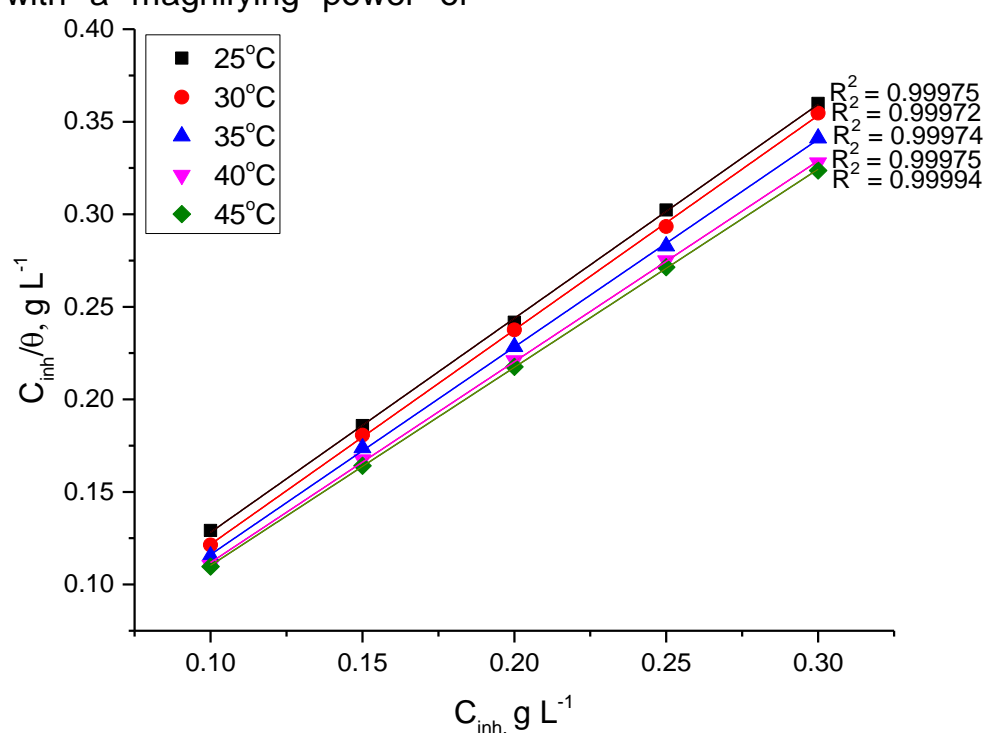

Figure 1. Langmuir plots at various temperatures for carbon steel in $1 \mathrm{M} \mathrm{HCl}$

Slika 1. Langmuir-ove krive na različitim temperaturama za ugljenični čelik u $1 \mathrm{M} \mathrm{HCl}$ 
The free energies of the adsorption process $\left(\Delta G_{\text {ads }}^{\circ}\right)$ were counted utilizing the following equation [46]:

$$
k_{a d s}=1 / 55.5 e^{(-\Delta G \circ a d s / R T)}
$$

Where $R$ is the universal gas constant $(8.314$ $\mathrm{J} /$ mole $\mathrm{K}$ ), $\mathrm{T}$ is the absolute temperature (Kelvin) and 55.5 is the value of water concentration at the solution bulk ( $\mathrm{mol} / \mathrm{L})$.
The Van't Hoff plot (Figure 2) is the method used to quickly determine the enthalpy of adsorption process $\left(\Delta \mathrm{H}^{\circ}\right.$ ads $)$ both qualitatively and quantitatively according to the following equation [47]:

$$
\log k_{a d s}=\left(-\Delta H^{\circ}{ }_{a d s} / 2.303 R T\right)+\text { constant }
$$

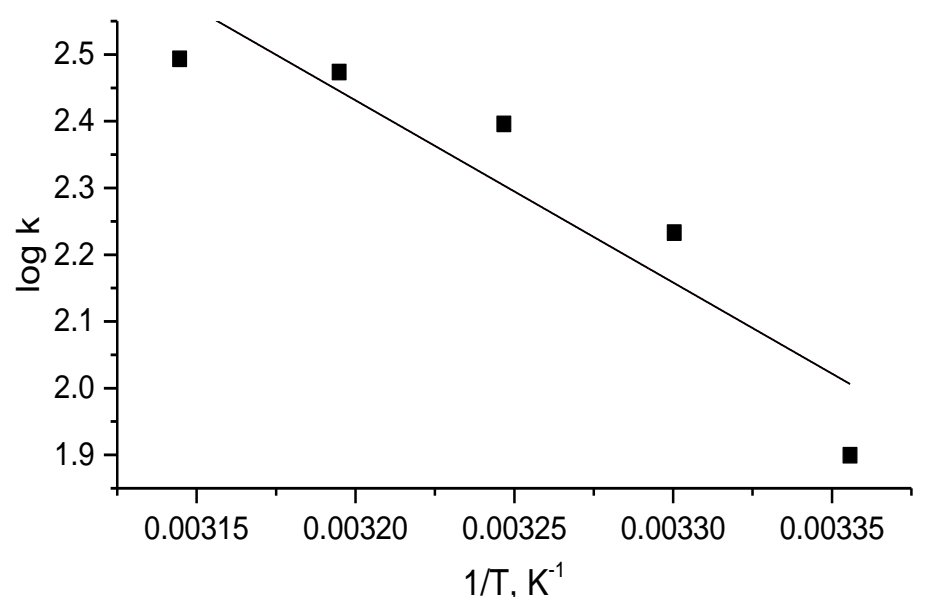

Figure 2. Van't Hoff plot (log $k_{a d s}$ of carbon steel against $1 / T$ ) in $1 \mathrm{M} \mathrm{HCl}$

Slika 2. Van't Hoff kriva (log $k_{a d s}$ of carbon steel against 1/T) u $1 \mathrm{M} \mathrm{HCl}$

The entropy of adsorption $\left(\Delta S^{\circ}{ }_{\text {ads }}\right)$, can be calculated using the basic thermodynamic principle equation as follows [46]:

$$
\Delta G^{o}{ }_{a d s}=\Delta H^{o}{ }_{a d s}-T \Delta S^{o}{ }_{a d s}
$$

The calculated data $\left(\mathrm{k}_{\text {ads }}, \Delta \mathrm{G}_{\mathrm{ads}}^{\circ}, \Delta \mathrm{H}\right.$. ads and $\Delta S$ ads) were tabulated in (Table 2). By analyzing the obtained results, we deduced that the sign of $\Delta \mathrm{G}^{\circ}$ ads is negative which indicating an spontaneous reaction. Besides, Besides, $\Delta \mathrm{G}_{\text {ads }}$ equals -20 $\mathrm{kJ} / \mathrm{mol}$ or lower are in agreement with physisorption, that includes electrostatic attraction between the charged molecules and the charged metal, while $\Delta \mathrm{G}_{\text {ads }}$ larger than $-40 \mathrm{~kJ} / \mathrm{mol}$ includes chemisorption, takes place by sharing or transfering the charge from the molecules to the surface. For the investigated cpmpound, $\Delta \mathrm{G}^{\circ}{ }_{\text {ads }}$ variation with temperature in the range from 20.8 to $25.8 \mathrm{kj} / \mathrm{mol}$ exhibiting physisorption. The computed value of $\Delta \mathrm{H}_{\text {ads }}$ was $52.3 \mathrm{kJmol}^{-1}$ with a positive sign demonstrating endothermic reaction and as it slightly exceed $40 \mathrm{~kJ} \mathrm{~mol}^{-1}$ which assumed to be more physisorption than chemisorption since, it didn't exceed $100 \mathrm{~kJ} \mathrm{~mol}^{-1}$ which results in that, physical and chemical adsorptions are both included [48]. The values of entropy of adsorption $\left(\Delta S^{\circ}{ }_{a d s}\right)$ were found to have positive signs, which indicated that adsorption reaction is attended by an increase in the disorder.
Table 2. Adsorption thermodynamic parameters for Damsissa extract on carbon steel surface after $150 \mathrm{~min}$ of exposure to $1 \mathrm{M} \mathrm{HCl}$ at various temperatures

Tabela 2. Adsorpcioni termodinamički parametri za ekstrakt Damsissa na površini ugljeničnog

\begin{tabular}{|c|c|c|c|c|}
\hline $\mathrm{T},{ }^{0} \mathrm{~K}$ & kads & $\begin{array}{l}-\Delta \mathrm{G}_{\text {ads, }}^{\circ} \\
\mathrm{kJ} \mathrm{mol}^{-1}\end{array}$ & $\begin{array}{l}\Delta \mathrm{H}^{\circ} \text { ads, } \\
\mathrm{kJ} \mathrm{mol}^{-1}\end{array}$ & $\begin{array}{c}\Delta \mathrm{S}_{\text {adss }} \\
\mathrm{J} \mathrm{mol}^{-1} \mathrm{~K}^{-1}\end{array}$ \\
\hline 298 & 79.3 & 20.8 & \multirow{5}{*}{52.3} & 245.2 \\
\hline 303 & 170.9 & 23.1 & & 248.7 \\
\hline 308 & 248.8 & 24.4 & & 249.0 \\
\hline 313 & 297.6 & 25.3 & & 247.8 \\
\hline 318 & 311.5 & 25.8 & & 245.5 \\
\hline
\end{tabular}
čelika nakon 150 min izlaganja u $1 \mathrm{M} \mathrm{HCl}$ pri različitim temperaturama

\subsubsection{Effect of Temperature}

Weight loss is a chemical method utilized to show the influence of temperature on carbon steel corrosion in the absence and presence of various concentrations of Damsissa extract. Weight loss $(\Delta \mathrm{W})$ with time for carbon steel in $1 \mathrm{M} \mathrm{HCl}$ solution with $300 \mathrm{ppm}$ of Damsissa extract at various temperatures $\left(25,30,35,40,45^{\circ} \mathrm{C}\right)$ is shown in Figure 3. As appeared in the figure, the weight loss increases with increasing the temperature from $25^{\circ} \mathrm{C}$ till reached $45^{\circ} \mathrm{C}$ for $300 \mathrm{ppm}$. This can be explained according to the rule that, higher 
temperatures might give rise to desorption of increase as the temperature increases. \%IE Damsissa extract from the surface of carbon steel [49]. Figure 4 demonstrates that the corrosion rates $\left(k_{\text {corr }}\right)$ of the carbon steel in $1 \mathrm{M} \mathrm{HCl}$ decrease as

the Damsissa concentration increases, and (calculated utilizing equation 1 ) and $k_{\text {corr }}$ for various concentrations of Damsissa at various temperatures $\left(25 ; 30 ; 35 ; 40 ; 45^{\circ} \mathrm{C}\right)$ are shown in Table 3.

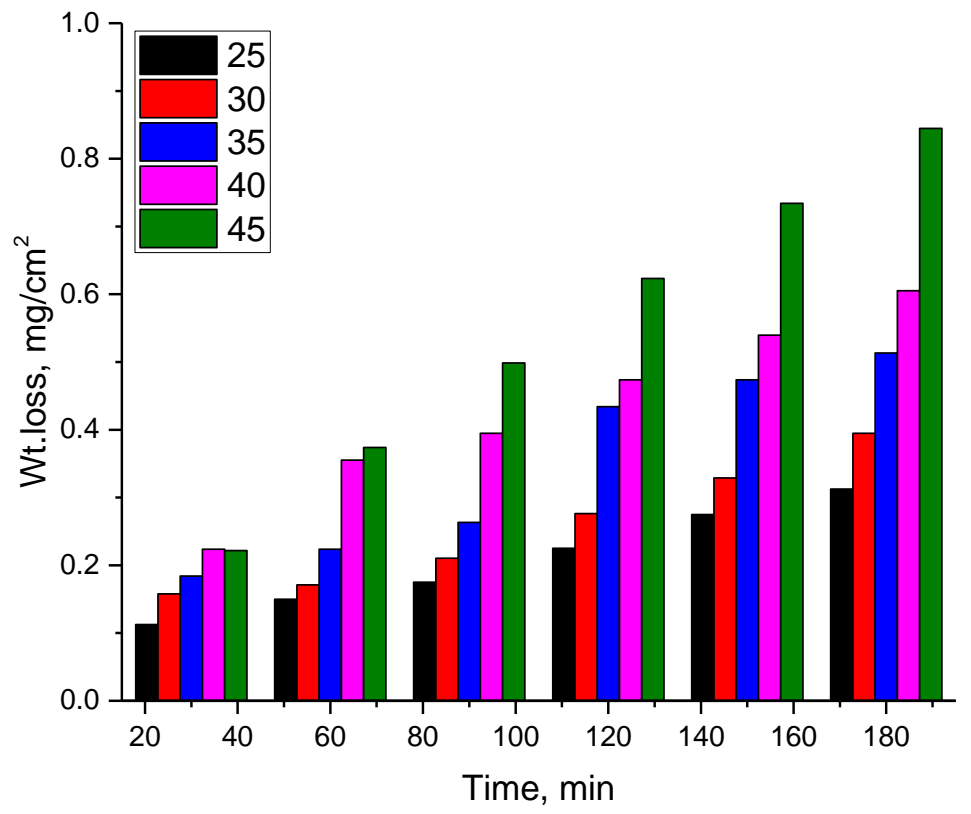

Figure 3. $\Delta W$ of carbon steel with time for $300 \mathrm{ppm}$ concentration of Damsissa extract in $1 \mathrm{M} \mathrm{HCl}$ at various temperatures

Slika 3. $\Delta W$ ugljeničnog čelika sa vremenom za 300 ppm koncentracije Damsissa ekstrakta u $1 \mathrm{M} \mathrm{HCl}$ pri različitim temperaturama

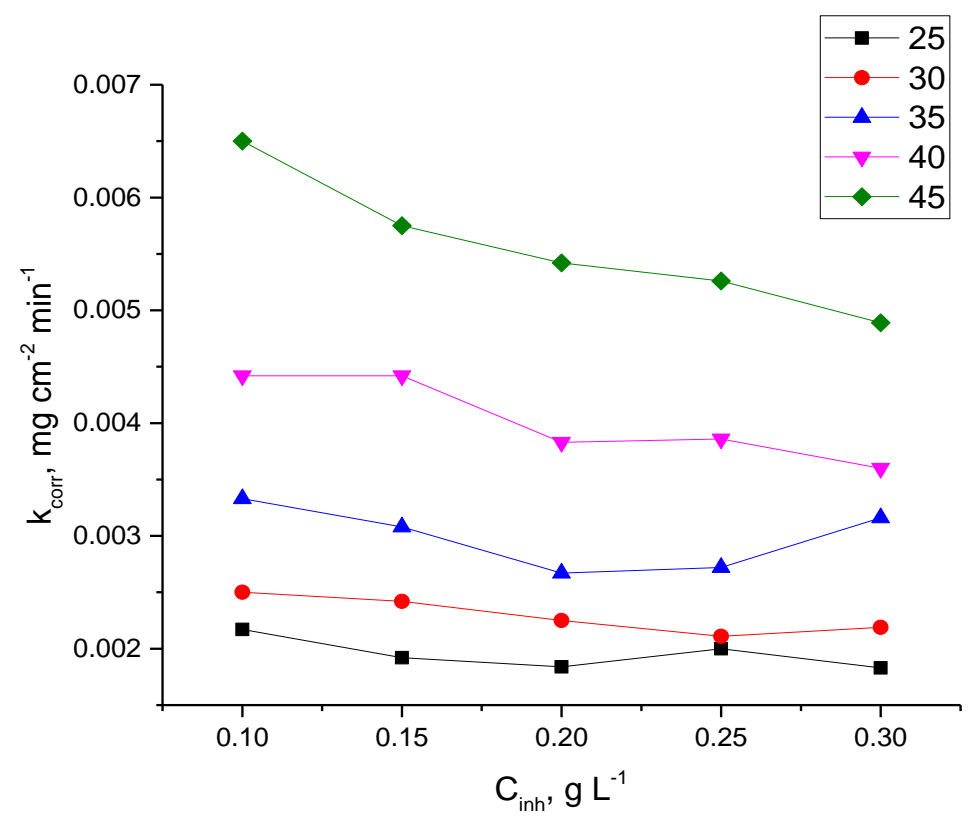

Figure 4. Corrosion rates of carbon steel against the concentration of Damsissa extract in $1 \mathrm{M} \mathrm{HCl}$ at various temperatures

Slika 4. Brzine korozije ugljeničnog čelika u odnosu na koncentraciju ekstrakta Damsissa u $1 \mathrm{M} \mathrm{HCl}$ pri različitim temperaturama 
Table 3. $k_{\text {corr }}$ and \%IE of various concentrations of Damsissa extract after 150 min immersion of the carbon steel in $1 \mathrm{M} \mathrm{HCl}$ solution at various temperatures

Tabela 3. $k_{\text {corr }} i$ \%IE pri različitim koncentracijama ekstrakta Damsissa nakon 150 min uranjanja ugljeničnog čelika u $1 \mathrm{M} \mathrm{HCl}$ rastvor pri različitim temperaturama

\begin{tabular}{|c|c|c|c|c|c|c|c|c|c|c|}
\hline \multirow{2}{*}{$\begin{array}{c}\text { Conc, } \\
\mathrm{ppm}\end{array}$} & \multicolumn{2}{|c|}{$25^{\circ} \mathrm{C}$} & \multicolumn{2}{c|}{$30^{\circ} \mathrm{C}$} & \multicolumn{2}{c|}{$35^{\circ} \mathrm{C}$} & \multicolumn{2}{c|}{$40^{\circ} \mathrm{C}$} & \multicolumn{2}{c|}{$45^{\circ} \mathrm{C}$} \\
\cline { 2 - 11 } & $\begin{array}{c}\mathrm{k}_{\text {corr, }} \mathrm{mg} \mathrm{cm}^{-2} \\
\mathrm{~min}^{-1}\end{array}$ & $\% \mathrm{IE}$ & $\begin{array}{c}\mathrm{k}_{\text {corr, }} \mathrm{mg} \mathrm{cm}^{-2} \\
\mathrm{~min}^{-1}\end{array}$ & $\% \mathrm{IE}$ & $\begin{array}{c}\mathrm{k}_{\text {corr, }} \mathrm{mg} \mathrm{cm}^{-2} \\
\mathrm{~min}^{-1}\end{array}$ & $\% \mathrm{IE}$ & $\begin{array}{c}\mathrm{k}_{\text {corr, }} \mathrm{mg} \mathrm{cm}^{-2} \\
\mathrm{~min}^{-1}\end{array}$ & $\% \mathrm{IE}$ & $\begin{array}{c}\mathrm{k}_{\text {corr, }} \mathrm{mg} \mathrm{cm}^{-2} \\
\mathrm{~min}^{-1}\end{array}$ & $\% \mathrm{IE}$ \\
\hline 100 & 0.00217 & 81.6 & 0.00250 & 82.4 & 0.00333 & 88.6 & 0.00442 & 89.6 & 0.00650 & 90.2 \\
\hline 150 & 0.00192 & 83.7 & 0.00242 & 83.0 & 0.00308 & 89.4 & 0.00442 & 89.6 & 0.00575 & 91.4 \\
\hline 200 & 0.00184 & 84.3 & 0.00225 & 84.2 & 0.00267 & 90.9 & 0.00383 & 91 & 0.00542 & 91.9 \\
\hline 300 & 0.00183 & 84.4 & 0.00219 & 84.6 & 0.00316 & 89.2 & 0.00360 & 91.5 & 0.00489 & 92.7 \\
\hline
\end{tabular}

The activation energies $\left(E_{\mathrm{a}}^{*}\right)$ of the corrosion process were obtained by plotting corrosion rates of carbon steel $\left(k_{\text {corrr }}\right)$ against temperature $(1000 / T)$ (Figure 5). The $\mathrm{E}_{\mathrm{a}}$ values were gotten from the straight lines slopes (slope $=-\mathrm{E}_{\mathrm{a}}^{*} / 2.303 \mathrm{R}$ ) according to the following Arrhenius equation [50]:

$$
\log k_{\text {corr }}=\log A-\left(E_{a}^{*} / 2.303 R\right) 1 / T
$$

Where $A$ is a pre-exponential factor. Both activation enthalpy $\left(\Delta \mathrm{H}^{*}\right)$ and activation entropy $\left(\Delta \mathrm{S}^{*}\right)$ of the corrosion reaction can be getting via plotting log $\mathrm{k}_{\text {corr }} / \mathrm{T}$ against 1000/T (Figure 6), resulting in straight lines (slope $=-\Delta \mathrm{H}^{*} / 2.303 \mathrm{R}$ and intercept $=\log \left(\mathrm{R} / \mathrm{Nh}+\Delta \mathrm{S}^{*} / 2.303 \mathrm{R}\right)$ as indicated in the next Transition state equation [50].

$$
\begin{aligned}
& \log k_{\text {corr }} / T=\log \left(R / N h+\Delta S^{*} / 2.303 R\right)+ \\
& +\left(-\Delta H^{*} / 2.303 R\right) 1 / T
\end{aligned}
$$

Where $\mathrm{h}$ is Planck's constant, $\mathrm{N}$ is Avogadro's number. The obtained activation parameters are tabulated in Table 4.

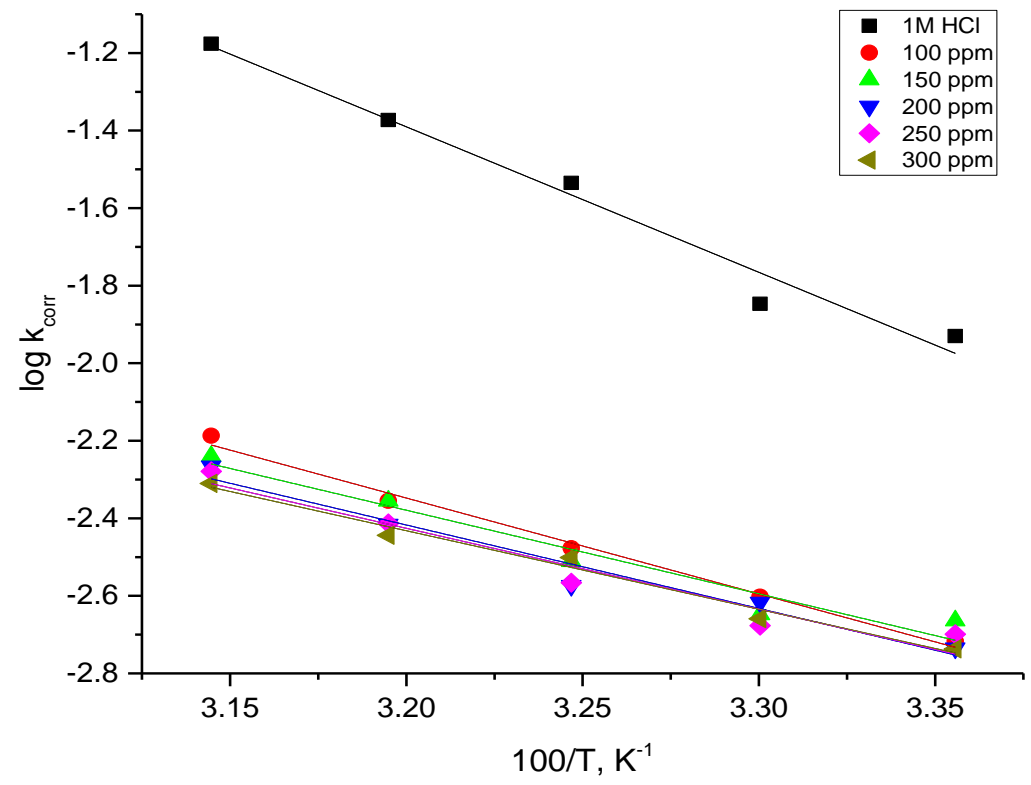

Figure 5. $\log k_{\text {corr }}$ of carbon steel against 1000/T in the absence and presence of various concentrations of Damsissa extract in $1 \mathrm{M} \mathrm{HCl}$ at $25^{\circ} \mathrm{C}$

Slika 5. log k korr ugljeničnog čelika pri 1000/T u odsustvu i prisustvu različitih koncentracija ekstrakta Damsissa u $1 \mathrm{M} \mathrm{HCl} \mathrm{na} 25^{\circ} \mathrm{C}$ 


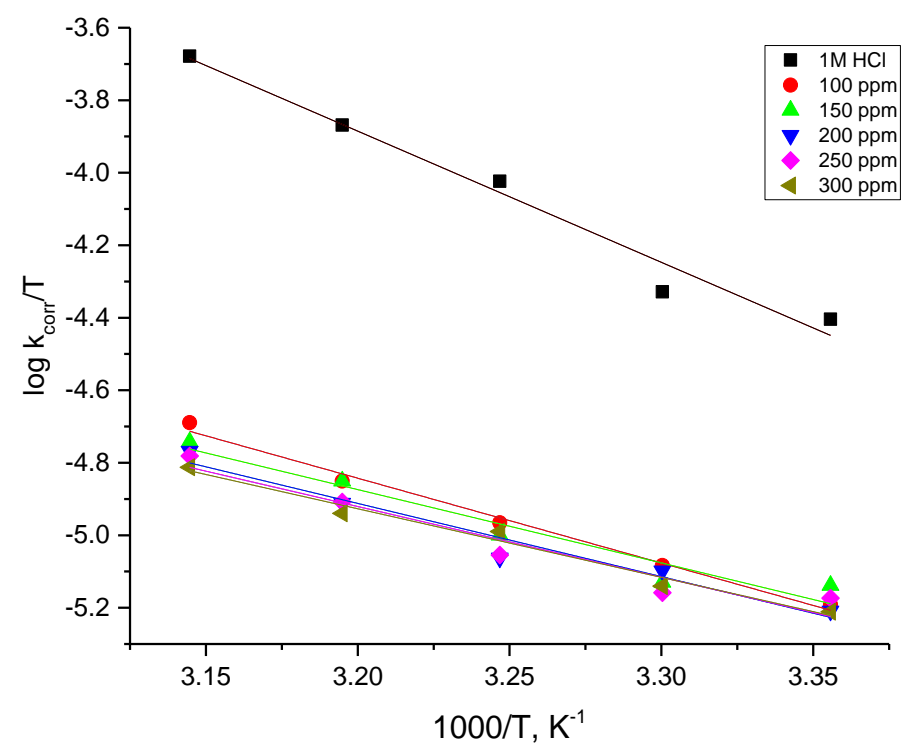

Figure 6. $\log k_{\text {corr }}$ of carbon stee I/T against 1000/T in the absence and presence of various concentrations of Damsissa extract in $1 \mathrm{M} \mathrm{HCl}$ at $25^{\circ} \mathrm{C}$

Slika 6. log k $k_{\text {corr }}$ ugljeničnog čelika kroz I/T prema 1000/T u odsustvu i prisustvu različitih koncentracija ekstrakta Damsissa u $1 \mathrm{M} \mathrm{HCl}$ na $25^{\circ} \mathrm{C}$

Table 4. $E_{a}{ }^{*}, \Delta H^{*}$ and $\Delta S^{*}$ for carbon steel after 150 min of exposure to $1 \mathrm{M} \mathrm{HCl}$ in the absence and presence of Damsissa extract

Tabela 4. $E_{a}{ }^{*}, \Delta H^{*} i \Delta S^{*}$ za ugljenični čelik nakon 150 min izlaganja u $1 \mathrm{M} \mathrm{HCl} \mathrm{u} \mathrm{odsustvu} \mathrm{i} \mathrm{prisustvu} \mathrm{ekstrakta}$ Damsissa

\begin{tabular}{|c|c|c|c|}
\hline $\begin{array}{c}\text { Conc, } \\
\mathrm{ppm}\end{array}$ & $\begin{array}{c}\mathrm{E}^{*}{ }^{*}, \\
\mathrm{~kJ} \mathrm{~mol}^{-1}\end{array}$ & $\begin{array}{c}\Delta \mathrm{H}^{*}, \\
\mathrm{~kJ} \mathrm{~mol}^{-1}\end{array}$ & $\begin{array}{c}\Delta \mathrm{S}^{*}, \\
\mathrm{~J} \mathrm{~mol}^{-1} \mathrm{k}^{-1}\end{array}$ \\
\hline $1 \mathrm{M} \mathrm{HCl}$ & 71.9 & 69.27 & -50.18 \\
\hline 100 & 47.4 & 44.78 & -146.87 \\
\hline 150 & 41.3 & 38.69 & -166.96 \\
\hline 200 & 41.2 & 38.64 & -167.84 \\
\hline 250 & 39.9 & 37.32 & -172.23 \\
\hline 300 & 38.8 & 36.20 & -175.93 \\
\hline
\end{tabular}

As shown in the above table, $\mathrm{E}_{\mathrm{a}}^{*}$ has lower value in the solution with the extract compared with that without the extract. The decrease in the activation energy in the inhibited solutions signalizes the higher inhibition efficiency of Damsissa extract. The decrease of the activation energy refers to the adsorption of Damsissa extract on the surface of the carbon steel, producing a stable metal-inhibitor complex [51]. The positive sign of $\Delta \mathrm{H}^{*}$ indicates endothermic process, that requires more energy to realize the equilibrium [52] and also indicates strong adsorption ability of Damsissa extract on the carbon steel surface [53]. The negative values of $\Delta S^{*}$ signalize that the activated complex in the rate determining stage demonstrates an association not a dissociation, that indicates the lowering in disorder comes through the course of moving from the reactants to the activated complex [54]. In addition, the values of $\Delta S^{*}$ become more and more negative as the concentration of Damsissa extract increases, this indicates that the presence of Damsissa extract makes the activated complex more order.

\subsection{Potentiodynamic Polarization}

The curves of potentiodynamic polarization for corrosion of carbon steel in $1 \mathrm{M} \mathrm{HCl}$ in the absence and presence of various concentrations of Damsissa extract at $25^{\circ} \mathrm{C}$ were recorded in Figure 7. The degree of surface coverage $(\theta)$ and the inhibition efficiency (\%IE) of potentiodynamic polarization tests were computed utilizing equation (2), then tabulated in Table 5 together with the corrosion potential $\left(E_{\text {corr }}\right)$, the corrosion current density ( $\left.i_{\text {corr }}\right)$, the cathodic $\left(\beta_{\mathrm{c}}\right)$ \& anodic $\left(\beta_{\mathrm{a}}\right)$ Tafel slopes and the corrosion rate (C.R). 


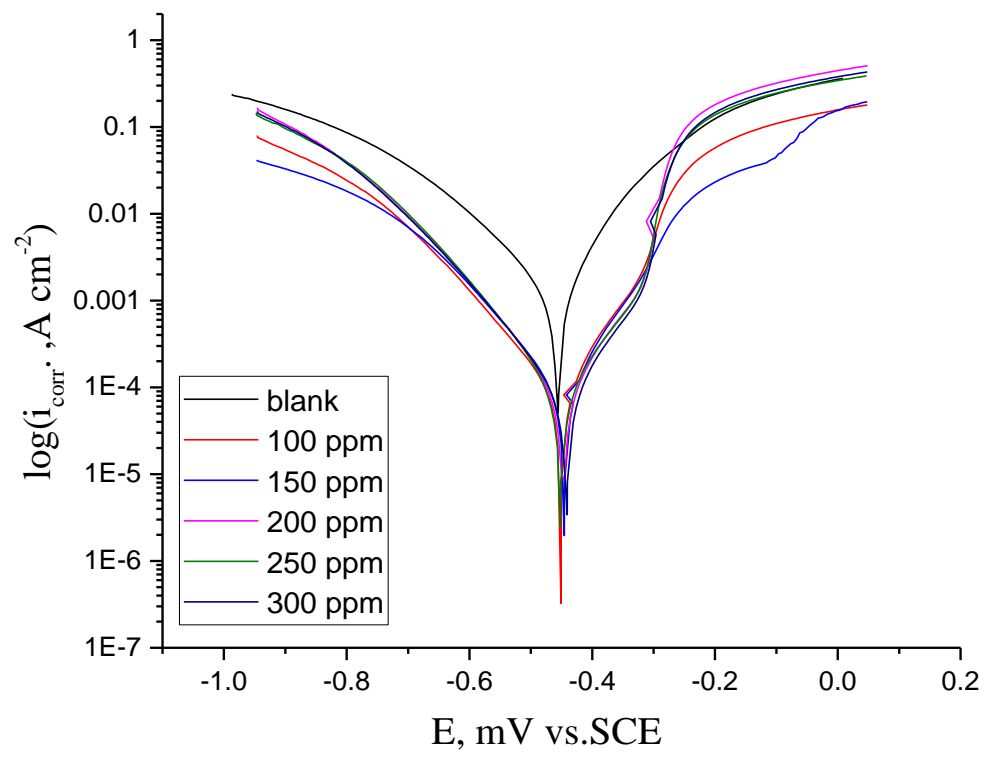

Figure 7. Tafel plots for carbon steel in $1 \mathrm{M} \mathrm{HCl}$ in the absence and presence various concentrations of Damsissa extract at $25^{\circ} \mathrm{C}$

Slika 7. Tafel-ove krive za ugljenični čelik u $1 \mathrm{M} \mathrm{HCl}$ u odsustvu i prisustvu različitih koncentracija ekstrakta Damsissa na $25^{\circ} \mathrm{C}$

Table 5. Effect of the Damsissa extract on corrosion parameters of carbon steel in $1 \mathrm{M} \mathrm{HCl}$ as obtained utilizing potentiodynamic polarization at $25^{\circ} \mathrm{C}$

Tabela 5. Uticaj ekstrakta Damsisse na parametre korozije ugljeničnog čelika u $1 \mathrm{M} \mathrm{HCl} \mathrm{dobijenog} \mathrm{korišćenjem}$ potenciodinamičke polarizacije na $25^{\circ} \mathrm{C}$

\begin{tabular}{|c|c|c|c|c|c|c|c|}
\hline $\begin{array}{c}\text { Conc, } \\
\mathrm{ppm}\end{array}$ & $\begin{array}{c}-\mathrm{E}_{\text {corr, }} \\
\mathrm{mV} \text { vs.SCE }\end{array}$ & $\begin{array}{c}\mathrm{i}_{\mathrm{cor},} \\
\mu \mathrm{A} \mathrm{cm}^{-2}\end{array}$ & $\begin{array}{c}\beta_{\mathrm{c},} \\
\mathrm{mVdec}^{-1}\end{array}$ & $\begin{array}{c}\beta_{\mathrm{a},} \\
\mathrm{mV} \mathrm{dec}^{-1}\end{array}$ & $\begin{array}{c}\text { C.R, } \\
\mathrm{mpy}\end{array}$ & $\theta$ & $\% \mathrm{IE}$ \\
\hline $1 \mathrm{M} \mathrm{HCl}$ & 457.0 & 1190 & 153.4 & 95.9 & 550.00 & $\ldots \ldots$ & $\ldots \ldots$ \\
\hline 100 & 451.0 & 105 & 142.2 & 102.3 & 48.07 & 0.912 & 91.2 \\
\hline 150 & 445.0 & 104 & 135.2 & 98.2 & 47.64 & 0.913 & 91.3 \\
\hline 200 & 447.0 & 101 & 133.6 & 104.1 & 46.10 & 0.915 & 91.5 \\
\hline 250 & 452.0 & 98.4 & 125.0 & 110.2 & 44.94 & 0.917 & 91.7 \\
\hline 300 & 442.0 & 87.9 & 126.4 & 108.9 & 40.17 & 0.926 & 92.6 \\
\hline
\end{tabular}

The values of the cathodic Tafel slope $(\beta c)$ and the anodic Tafel ones ( $\beta a)$ (shown in Table 5) are slightly shifted from the blank, which confirms the view that Damsissa extract was capable of suppressing the cathodic hydrogen evolution and the anodic dissolution together, by making a protective layer on the carbon steel surface. In general words, the inhibitor is classified to anodic or cathodic if the corrosion potential $\left(E_{\text {corr }}\right)$ value is shifted to more than $85 \mathrm{mV}$ with respect to the blank $[55,56]$. As indicated in Table 5, there was no significant change observed in the corrosion potential $\left(E_{\text {corr }}\right)$, as it recorded a minimum change of $5 \mathrm{mV}$ and a maximum change of $15 \mathrm{mV}$, which indicated that Damsissa extract is a mixed type in nature.

\subsection{EIS Technique}

EIS is a good method utilizing for investigation the carbon steel corrosion in acid solution. EIS measurements were done in $1 \mathrm{M} \mathrm{HCl}$ solution in the absence and presence of various concentrations of the Damsissa extract. The diameter of a semicircle of the Nyquist plots (Figure 8) increases as a result of increasing the extract concentration, that indicates the formation of a protective layer of the extract at the carbon steel - solution interface.

Figure 9 demonstrates the Bode plots, which show that the phase angle was shifted with a large value in the inhibited solutions compared with uninhibited one, and this shift increases as the extract concentration increases. This referred to the reduction of the metal dissolution and the capacitive behavior on the electrode surface [57].

The results of EIS measurements were simulated utilizing the illustrated equivalent circuit (Figure 10), in which $R_{s}$ is the solution resistance, $R_{c t}$ is the charge transfer resistance and CPE is the constant phase element. Introduction of $\mathrm{CPE}$ 
instead of a pure double layer capacitor in the circuit gives a more accurate fit [58]. For calculating the inhibition efficiency, equation (3) is used, while equation (10) is used for calculating double layer capacitance $\left(\mathrm{C}_{\mathrm{dl}}\right)[59]$.

$$
C_{d l}=Y_{o}\left(2 \pi f_{\max }\right)^{n-1}
$$

Where $Y_{0}$ is the magnitude of the CPE, $f_{\max }$ is the frequency at which the imaginary component of the impedance is maximum and $\mathrm{n}$ is an adjustable parameter lies between 0.50 and 1.0. The data obtained from EIS test were tabulated in Table 6. The results show a significant increase in the charge transfer resistance $\left(R_{c t}\right)$ with increasing the extract concentration, which refers to the increase in the surface coverage. The decrease in $\mathrm{C}_{\mathrm{dl}}$ in inhibiting solutions, compare with uninhibited one, is due to the reduction of the local dielectric constant and the increasing of the protective inhibitor double layer thickness, indicating that organic derivatives prevent the carbon steel corrosion through adsorption at metal/acid $[60,61]$.

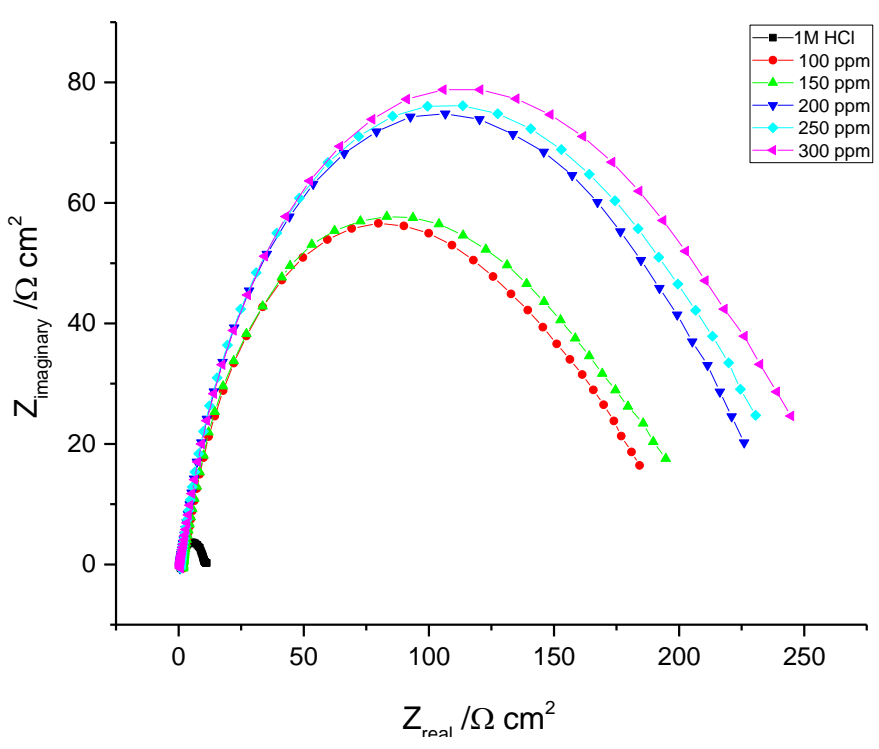

Figure 8. Nyquist plots for carbon steel corrosion in $1 \mathrm{M} \mathrm{HCl}$ in the absence and presence of various concentrations of Damsissa extract at $25^{\circ} \mathrm{C}$

Slika 8. Nyquist-ove krive za koroziju ugljeničnog čelika u $1 \mathrm{M} \mathrm{HCl} \mathrm{u} \mathrm{odsustvu} \mathrm{i} \mathrm{prisustvu} \mathrm{različitih}$ koncentracija ekstrakta Damsissa na $25^{\circ} \mathrm{C}$

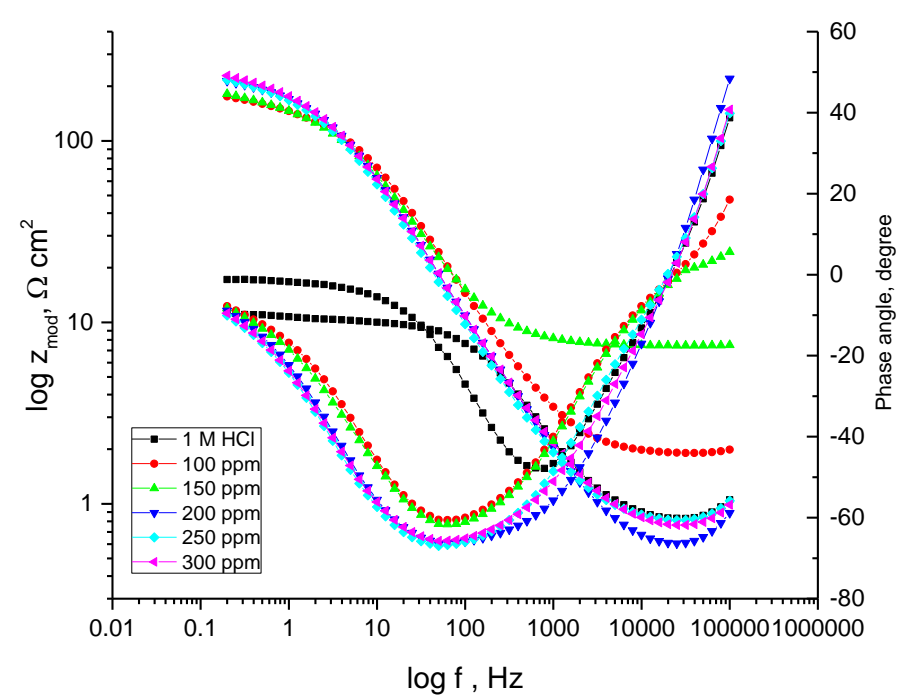

Figure 9. Bode plots for carbon steel corrosion in $1 \mathrm{M} \mathrm{HCl}$ in the absence and presence of various concentrations of Damsissa extract at $25^{\circ} \mathrm{C}$

Slika 9. Bode-ove krive za koroziju ugljeničnog čelika u $1 \mathrm{M} \mathrm{HCl} \mathrm{u} \mathrm{odsustvu} \mathrm{i} \mathrm{prisustvu} \mathrm{različitih}$ koncentracija ekstrakta Damsissa na $25^{\circ} \mathrm{C}$ 


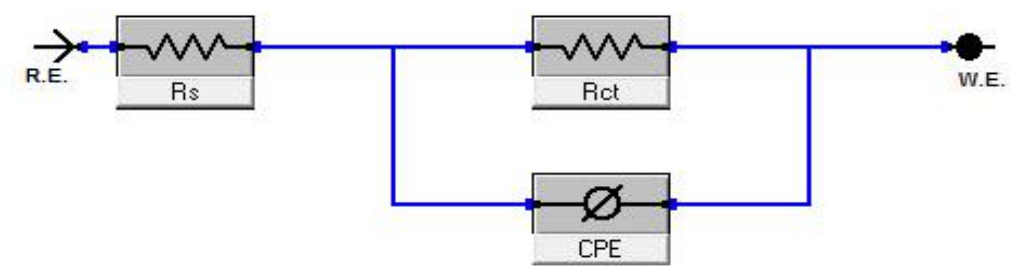

Figure 10. Equivalent circuit utilized for fitting EIS results

Slika 10. Ekvivalentno kolo koje se koristi za dobijanje EIS rezultata

Table 6. Data obtained from EIS test for carbon steel corrosion in $1 \mathrm{M} \mathrm{HCl}$ in the absence and presence of various concentrations of Damsissa extract at $25^{\circ} \mathrm{C}$

Tabela 6. Podaci dobijeni iz EIS testa za koroziju ugljeničnog čelika u $1 \mathrm{M} \mathrm{HCl} \mathrm{u} \mathrm{odsustvu} \mathrm{i} \mathrm{prisustvu} \mathrm{različitih}$ koncentracija ekstrakta Damsissa na $25^{\circ} \mathrm{C}$

\begin{tabular}{|c|c|c|c|c|}
\hline Conc, $\mathrm{ppm}$ & $\mathrm{Cdl}, \mu \mathrm{Fcm}-2$ & Rct, $\Omega \mathrm{cm} 2$ & $\Theta$ & $\% \mathrm{IE}$ \\
\hline $1 \mathrm{M} \mathrm{HCl}$ & $1.133 \times 10-4$ & 9.600 & ----- & $---{ }^{-}$ \\
\hline 100 & $2.206 \times 10-5$ & 171.3 & 0.944 & 94.4 \\
\hline 150 & $2.998 \times 10-5$ & 175.9 & 0.945 & 94.5 \\
\hline 200 & $2.916 \times 10-5$ & 214.0 & 0.955 & 95.5 \\
\hline 250 & $3.368 \times 10-5$ & 218.9 & 0.956 & 95.6 \\
\hline 300 & $3.171 \times 10-5$ & 232.0 & 0.959 & 95.8 \\
\hline
\end{tabular}

\subsection{Electrochemical Frequency Modulation (EFM)} Technique

Figure 11 appears the intermodulation spectrum of carbon steel in $1 \mathrm{M} \mathrm{HCl}$ in the absence and presence of various concentrations of Damsissa extract at $25^{\circ} \mathrm{C}$. The bigger peaks were utilized to compute $\mathrm{i}_{\text {corr }}, \beta_{\mathrm{c}}, \beta_{\mathrm{a}}$ and the causality factors CF-2 and CF-3 [62]. The biggest strength of the EFM comes from the causality factors, that serve as an internal examination on the rightness of the EFM measurement [63].

The inhibition efficiency \%IE (from EFM estimations) were computed by the method shown in equation (11), and all the gotten parameters via EFM test were tabulated in Table 7.

$\left.\% I E=\theta \times 100=1-\left[\left(i_{\text {Corr }}\right)_{E F M} /\left(i_{\text {OCOrr }}\right)_{E F M}\right)\right] \times 100$

Table 7. The parameters obtained by EFM test for carbon steel in $1 \mathrm{M} \mathrm{HCl}$ solution in the absence and presence various concentrations of Damsissa extract at $25^{\circ} \mathrm{C}$

Tabela 7. Parametri dobijeni EFM testom za ugljenični čelik u $1 \mathrm{M} \mathrm{HCl} \mathrm{u} \mathrm{odsustvu} \mathrm{i} \mathrm{prisustvu} \mathrm{različitih}$ koncentracija ekstrakta Damsissa na $25^{\circ} \mathrm{C}$

\begin{tabular}{|c|c|c|c|c|c|c|c|c|}
\hline $\begin{array}{c}\text { Conc, } \\
\mathrm{ppm}\end{array}$ & $\begin{array}{c}\mathrm{i}_{\text {corr, }} \\
\mu \mathrm{A} \mathrm{cm}\end{array}$ & $\begin{array}{c}\beta_{\mathrm{c}}, \\
\mathrm{mV} \mathrm{dec}^{-1}\end{array}$ & $\begin{array}{c}\beta_{\mathrm{a}}, \\
\mathrm{mV} \mathrm{dec}^{-1}\end{array}$ & CF-2 & CF-3 & $\begin{array}{c}\text { C.R. } \\
\mathrm{mpy}\end{array}$ & $\Theta$ & \%IE \\
\hline $1 \mathrm{M} \mathrm{HCl}$ & 844.3 & 128.7 & 80.5 & 1.887 & 2.843 & 385.8 & $\ldots \ldots \ldots$ & $\ldots \ldots \ldots$ \\
\hline 100 & 183.6 & 173.4 & 121.9 & 1.928 & 3.083 & 83.89 & 0.783 & 78.3 \\
\hline 150 & 173.5 & 164.2 & 129.3 & 2.016 & 2.645 & 79.29 & 0.795 & 79.5 \\
\hline 200 & 135.9 & 150.5 & 116.3 & 2.164 & 2.880 & 62.08 & 0.839 & 83.9 \\
\hline 250 & 128.1 & 138.4 & 115.9 & 2.339 & 3.029 & 58.52 & 0.848 & 84.8 \\
\hline 300 & 116.5 & 133.1 & 112.4 & 1.623 & 3.199 & 53.23 & 0.862 & 86.2 \\
\hline
\end{tabular}

The current density $\left(i_{\text {corr }}\right)$, which appeared in Table 7, seemed to decrease as the extract concentration increases, which caused a decrease in the corrosion rate (C.R) and so, the surface coverage $(\Theta)$ increasing, that leads to increasing the inhibition efficiency (\%IE) as the Damsissa extract concentration increases. The causality factors, as indicated by Table 7, are so near those of theoretical values (2.0 and 3.0), which confirm the rightness of Tafel slopes and current densities according to the EFM theory $[64,65]$. These data suggested that Damsissa extract reduces the corrosion occurred on the carbon steel surface through its mixed type nature. 

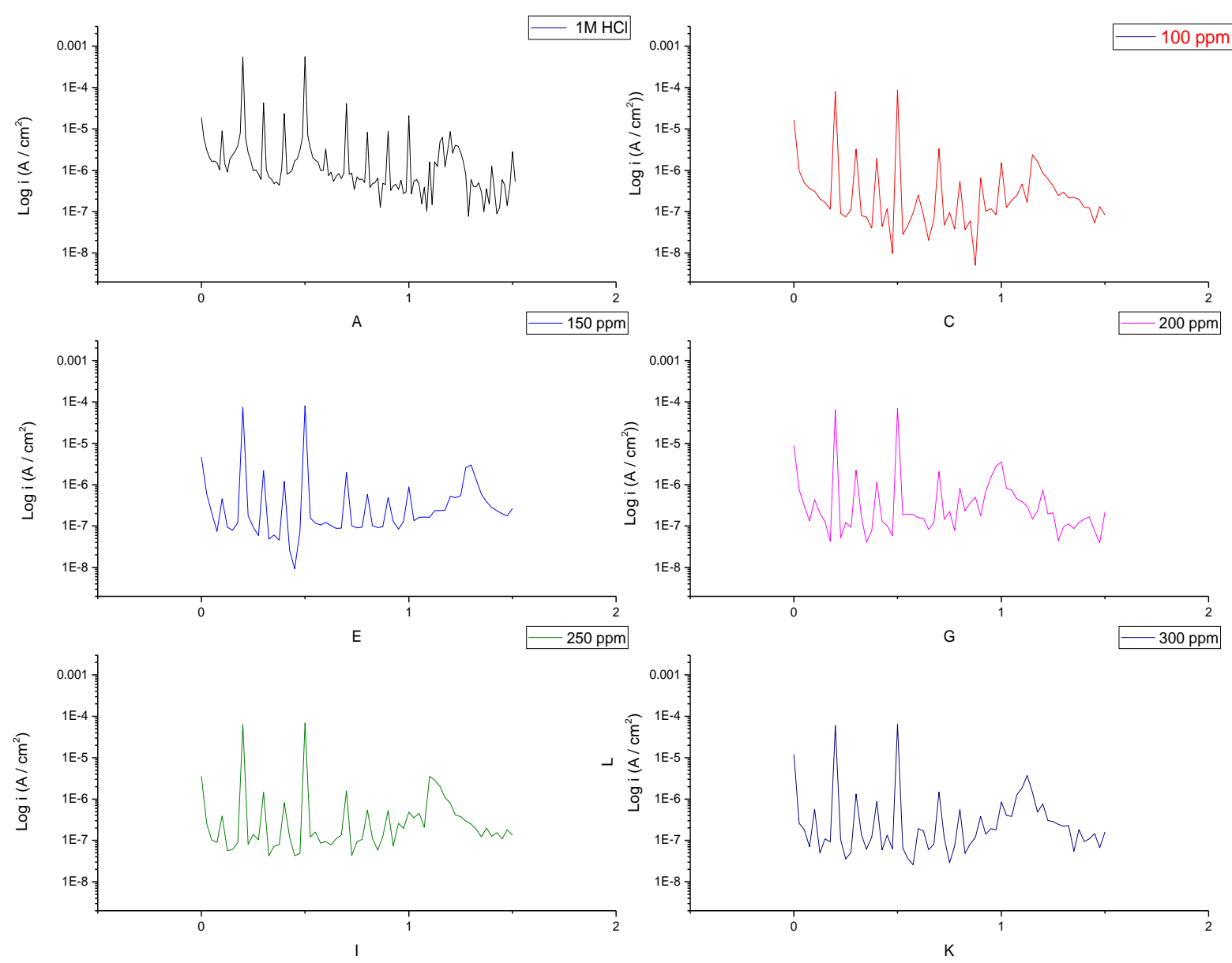

Figure 11. Intermodulation spectrum of carbon steel in $1 \mathrm{M} \mathrm{HCl}$ in the absence and presence of various concentrations of Dasissa extract at $25^{\circ} \mathrm{C}$.

Slika 11. Intermodulacioni spektar ugljeničnog čelika u $1 \mathrm{M} \mathrm{HCl} \mathrm{u} \mathrm{odsustvu} \mathrm{i} \mathrm{prisustvu} \mathrm{različitih}$ koncentracija Dasissa ekstrakta na $25^{\circ} \mathrm{C}$.

\subsection{Scanning Electron Microscopy (SEM)}

The surface morphology of carbon steel can be analyzed after $24 \mathrm{hr}$ in uninhibited and inhibited $1 \mathrm{M}$ $\mathrm{HCl}$ solution at $25^{\circ} \mathrm{C}$ using SEM technique. The pure carbon steel (Figure 12a) seemed to have a cracked surface, that is due to the drying process. The surface of the steel in uninhibited $\mathrm{HCl}$ solution (Figure 12b) was observed to be more distorted,
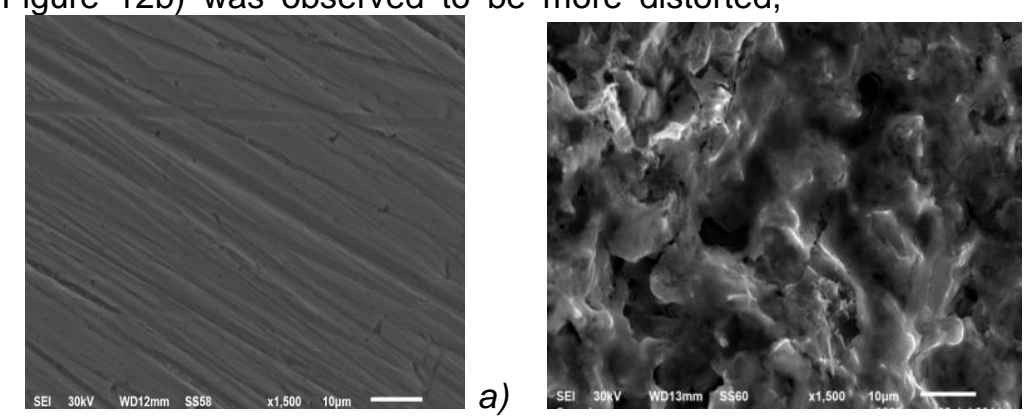

b)

that refers to the high dissolution rate of carbon steel in the acid solution without the inhibitor. On the other hand, a superfine and uniform layer on the carbon steel surface was observed in inhibited solution (Figure 12c), that is mean Damsissa extract was adsorbed on the surface of the carbon steel and form a protective layer that saves the surface from the corrosion in $1 \mathrm{M} \mathrm{HCl} \mathrm{[66].}$

Figure 12. The surface of the carbon steel electrode imaged using SEM (a) pure carbon steel, (b) in $1 \mathrm{M} \mathrm{HCl}$ and (c) in $1 \mathrm{M} \mathrm{HCl}$ with $300 \mathrm{ppm}$ of Damsissa

Slika 12. Površina elektrode ugljeničnog čelika snimljena korišćenjem SEM (a) čisti ugljenični čelik, (b) $u 1 \mathrm{M} \mathrm{HCl}$ (c) u $1 \mathrm{M} \mathrm{HCl}$ sa 300 ppm Damsissa 


\subsection{Atomic Force Microscopy (AFM)}

Further investigation of the ability of Damsissa extract to prevent the corrosion of carbon steel in $1 \mathrm{M} \mathrm{HCl}$ was studied by atomic force microscopy (AFM) technique in order to characterize the carbon steel surface microstructure. The AFM is deemed the most fitting device to measure the topography of the surface as it able to supply three dimensional (3D) information about surface morphology [67].

AFM images obtained for the carbon steel surface in $1 \mathrm{M} \mathrm{HCl}$ for $24 \mathrm{~h}$ at $25^{\circ} \mathrm{C}$ without and with $300 \mathrm{ppm}$ of Damsissa appeared in Figure 13a and Figure 13b, respectively. The absence of Damsissa extract made the surface rougher and distorted introducing a height of $1206.59 \mathrm{~nm}$ (Figure 13a), while smooth and uniform surface morphology can be seen in the existence of Damsissa extract resulting in a height of $725.25 \mathrm{~nm}$ (Figure 13b). The roughness calculations were done using the (Gwyddion software, version 2.48, win 64-bit). The mean square roughness (RMS) and average surface roughness $\left(R_{a}\right)$ of the carbon steel surface in uninhibited and inhibited $\mathrm{HCl}$ solution were shown in Table 8. The roughness of the inhibited surface decreases because a protective layer of the extract was formed on the carbon steel surface, which causes the decrease of the surface roughness and effectively prevents its corrosion in $1 \mathrm{M} \mathrm{HCl}[68]$.

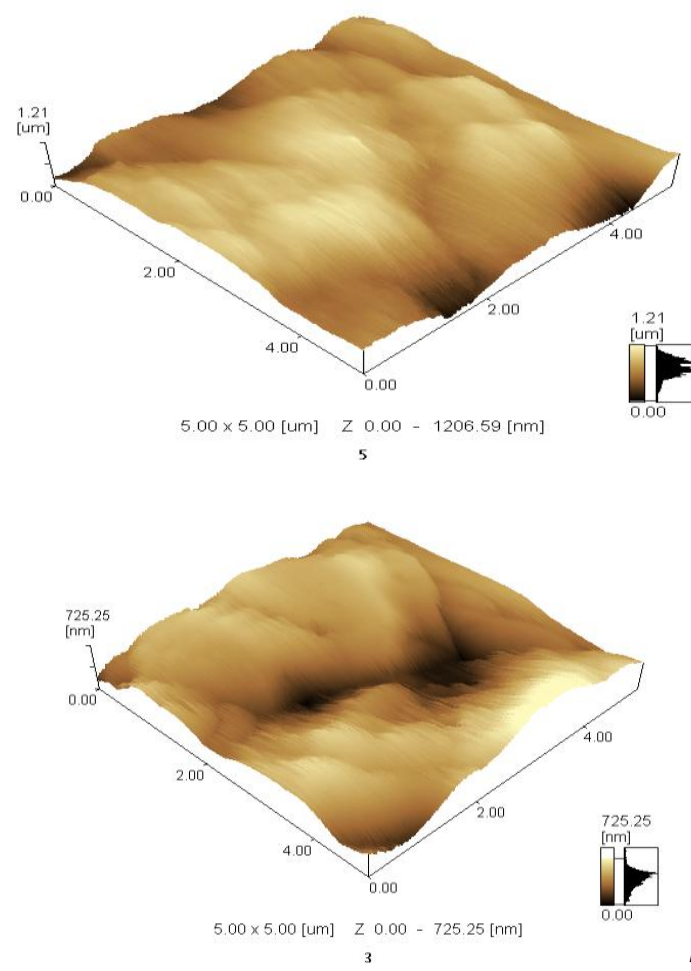

a)

Figure 13. AFM images of the carbon steel after exposure for $24 \mathrm{~h}$ to (a) $1 \mathrm{M} \mathrm{HCl}$ (b) $1 \mathrm{M} \mathrm{HCl}$ with 300ppm Damsissa extract

Slika 13. AFM slike ugljeničnog čelika nakon izlaganja $24 \mathrm{~h}$ (a) u $1 \mathrm{M} \mathrm{HCl}$ (b) u $1 \mathrm{M} \mathrm{HCl} \mathrm{sa}$ 300ppm ekstrakta Damsissa

Table 8. Height, mean square roughness (RMS) and average surface roughness ( $\left.R_{a}\right)$ of uninhibited and inhibited carbon steel surface in the $1 \mathrm{M} \mathrm{HCl}$ for $24 \mathrm{~h}$

Tabela 8. Visina, srednja kvadratna hrapavost (RMS) i srednja hrapavost površine (Ra) neinhibirane i inhibirane površine ugljeničnog čelika u $1 \mathrm{M} \mathrm{HCl} \mathrm{u} \mathrm{trajanju} \mathrm{od} 24 \mathrm{~h}$

\begin{tabular}{|c|c|c|}
\hline in $1 \mathrm{M} \mathrm{HCl}+300$ ppm Damssisa & in $1 \mathrm{M} \mathrm{HCl}$ & CS 1018 surface \\
\hline 725.25 & 1206.59 & Height $(\mathrm{nm})$ \\
\hline 31 & 47 & Mean square roughness [RMS] (ìm) \\
\hline 25 & 36 & Average roughness $\left[\mathrm{R}_{\mathrm{a}}\right](\mu \mathrm{m})$ \\
\hline
\end{tabular}

\subsection{Fourier Transform Infrared Spectroscopy} (FTIR)

FTIR analysis of the extract was utilized to characterize the functional groups in it, while that of the corrosion product was utilized to check that the inhibition comes from the interaction between the metal and the extract. The FTIR spectra for crude Damssisa, Damssisa in $1 \mathrm{M} \mathrm{HCl}$ solution and the corrosion products are presented in Figure 14. The results obtained indicate that the interaction between the extract and the carbon steel resulted in the inhibition process. FTIR of Damssisa in $1 \mathrm{M}$
$\mathrm{HCl}$ (Table 9) displayed that there are functional groups $\left(\mathrm{O} \_\mathrm{H}, \mathrm{N}-\mathrm{H}\right)$ contain oxygen and nitrogen atoms and unsaturated $(\mathrm{C}=\mathrm{C})$. The oxygen and nitrogen atoms in the extract give the general features of model corrosion inhibitors [69]. The shifts in the spectra with the addition of the carbon steel to Damssisa extract in $1 \mathrm{M} \mathrm{HCl}$ (Table 9) show that there is an interaction between Damssisa and the carbon steel through the functional groups present in the extract which resulted in inhibition. 


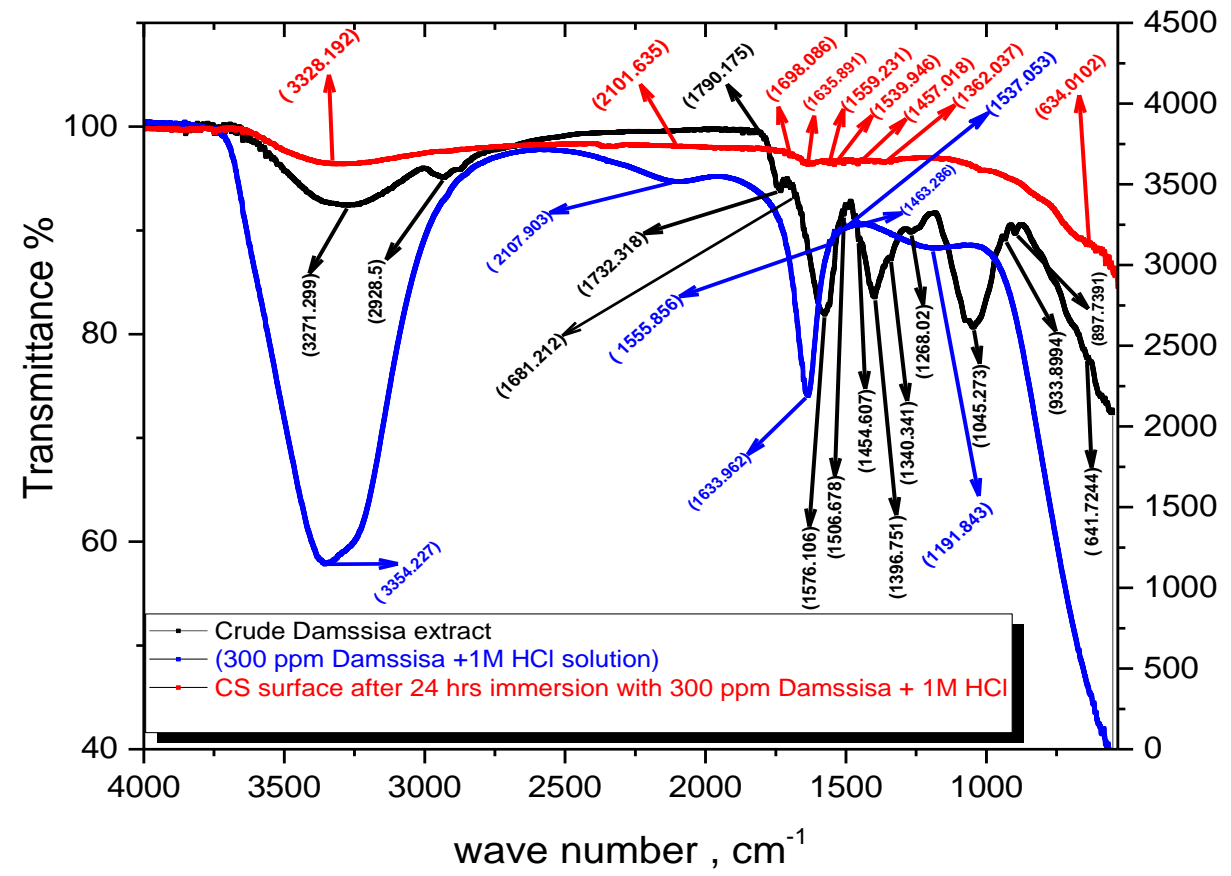

Figure 14. FTIR spectra of crude Damsissa, $\mathrm{HCl}$ extract of Damsissa and the corrosion product after $24 \mathrm{~h}$ immersion

Slika 14. FTIR spektri sirovog Damsissa, HCl ekstrakta Damsissa i proizvoda korozije nakon 24 sata uranjanja

Table 9. Observed wave numbers and the corresponding frequency assignment obtained from crude Damssisa, $\mathrm{HCl}$ extract of Damsissa and the corrosion product after $24 \mathrm{~h}$ of immersion

Tabela 9. Posmatrani broj talasa i odgovarajuća frekvencijska raspodela dobijena od sirovog Damssisa, $\mathrm{HCl}$ ekstrakta Damsissa i proizvoda korozije nakon 24 h potapanja

\begin{tabular}{|c|c|c|c|}
\hline \multicolumn{3}{|c|}{ Observed wave numbers $\left(\mathrm{cm}^{-1}\right)$} & \multirow{2}{*}{ Frequency Assignment } \\
\hline Crude Damssisa & $\begin{array}{c}300 \text { ppm Damssisa/ } 1 \mathrm{M} \\
\mathrm{HCl} \text { Solution }\end{array}$ & Corrosion products & \\
\hline 3271 & 3354 & 3328 & $\mathrm{O}-\mathrm{H} / \mathrm{N}-\mathrm{H}$ stretch \\
\hline 2930 & --- & --- & C-H stretch \\
\hline--- & 2108 & --- & $-\mathrm{C} \equiv \mathrm{C}-\mathrm{stretch}$ \\
\hline 1790 & \multirow{2}{*}{---} & \multirow{2}{*}{1698} & \multirow{2}{*}{$\mathrm{C}=\mathrm{O}$ stretch (carboxylic acids) } \\
\hline 1681 & & & \\
\hline 1732 & --- & --- & $\mathrm{C}=\mathrm{O}$ stretch (amides) \\
\hline--- & 1634 & 1636 & $-\mathbf{C}=\mathbf{C}-$ stretch \\
\hline 1575 & 1556 & 1559 & $\mathrm{~N}-\mathrm{H}$ bend \\
\hline 1507 & 1537 & 1540 & $\mathbf{C}=\mathbf{C}$ in ring aromatics \\
\hline 1455 & 1463 & 1457 & $\mathbf{C}-\mathbf{C}$ in ring aromatics \\
\hline 1397 & \multirow{2}{*}{---} & \multirow{2}{*}{1362} & \multirow{2}{*}{ C-H bend (rock) } \\
\hline 1339 & & & \\
\hline 1269 & \multirow{2}{*}{1192} & \multirow{2}{*}{---} & \multirow{2}{*}{-C-O stretch } \\
\hline 1047 & & & \\
\hline 934 & --- & --- & $\mathbf{O}-\mathbf{H}$ bend \\
\hline 898 & --- & 634 & $\mathrm{C}-\mathrm{H}$ bend (alkene) \\
\hline 641 & & & \\
\hline
\end{tabular}




\section{CONCLUSIONS}

The inhibitory influence of the Damsissa extract on carbon steel corrosion in $1 \mathrm{M} \mathrm{HCl}$ solution was shown in the present work utilizing weight loss, potentiodynamic polarization, EIS, EFM measurements and SEM\&AFM surface analysis, leading to the following outcomes:

1- Weight loss tests show that the addition of Damsissa extract to the carbon steel in $1 \mathrm{M} \mathrm{HCl}$ solution significantly reduced $\mathrm{k}_{\text {corr }}$, and increased \%IE, that decreases with temperature.

2- Adsorption isotherm of Damsissa extract on carbon steel surface can be explained by Langmuir isotherm. According to the obtained values of $\Delta \mathrm{G}^{\circ}$ ads, the physisorption was considered.

3- The obtained values of $\Delta G^{\circ}$ ads at different temperatures signalized that the adsorption of Damsissa extract on the surface is spontaneous. $\Delta \mathrm{H}^{\circ}$ ads values are positive, indicating endothermic adsorption. The disorder of the adsorption process increases because the $\Delta S^{\circ}$ ads values are positive.

4- Potentiodynamic polarization curves indicated that the extract inhibits both metal dissolution and hydrogen evolution.

5- EIS measurements indicated that the \%IE increases by increasing the concentration of the extract.

6- The inhibitory influence of Damsissa was further confirmed by AFM measurements, where it was shown that Damsissa decreases the carbon steel surface roughness and effectively prevents its corrosion.

8- AFM, SEM and FTIR surface analytical techniques confirmed that a protective layer of Damsissa extract is formed on the metal surface in $1 \mathrm{M} \mathrm{HCl}$.

\section{REFERENCES}

[1] M. Saadouni, M. Larouj, R. Salghi, H. Lgaz, S Jodeh, M. Zougagh, A. Souizi (2016) Evaluation of corrosion inhibition of mild steel in $1.0 \mathrm{M} \mathrm{HCl}$ by Sulfathiazole: Experimental and theoretical studies, Der Pharm. Lett., 8 (4), 96-107.

[2] M. Larouj, H. Lgaz, H. Zarrok, H. Serrar, H Zarrok, H. Bourazmi, A. Zarrouk, A. Elmidaoui, A. Guenbour, S. Boukhris, H. Oudda (2015) Adsorption properties and inhibition of carbon steel corrosion in hydrochloric acid solution by Ethyl 3hydroxy-8-methyl-4-oxo-6-phenyl-2-(p-toly)-4,6dihydropyrimido $[2,1-\mathrm{b}][1,3]$ thiazine-7-carboxylate, J. Mater. Environ. Sci., 6 (11), 3251-3267.
[3] M.Larouj, M.Belkhaouda, H.Lgaz, R.Salghi, S.Jodeh, S.Samhan, H.Serrar, S.Boukhris, M. Zougagh, H.Oudda (2016) Experimental and theoretical study of new synthesized organic compounds on corrosion behaviour and the inhibition of carbon steel in hydrochloric acid solution, Der Pharm. Chem., 8(2),114-133.

[4] H.Lgaz, O.Benali, R.Salghi, S.Jodeh, M.Larouj, O.Hamed, M.Messali, S.Samhan, M.Zougagh, H.Oudda (2016) 1Pyridinium derivatives as corrosion inhibitors for mild steel in $1 \mathrm{M} \mathrm{HCl}$ : Electrochemical, surface and quantum chemical studies, Der Pharm. Chem., 8(2), 172-190.

[5] L.Afia, M.Larouj, H.Lgaz, R.Salghi, S.Jodeh, S. Samhan, M.Zougagh (2016) Electrochemical and DFT calculation studies on corrosion inhibition of 2(2 Pyridyl) benzimidazole for C38 steel in hydrochloric acid solution, Der Pharm. Chem., 8(2), 2235.

[6] H.Lgaz, Y.ELaoufir, Y.Ramli, M.Larouj, H.Zarrok, R. Salghi, A.Zarrouk, A. Elmidaoui, A.Guenbour, M. EL Essassi, H.Oudda (2015) Synergistic effect of potassium iodide with (E)-3-(4 methoxystyryl) quinoxalin $2(1 \mathrm{H})$-one on the corrosion inhibition of carbon steel in $1.0 \mathrm{M} \mathrm{HCl}$, Der Pharm. Chem., 7(6), 36-45.

[7] B.EL.Makrini, M.Larouj, H.Lgaz, R.Salghi, A.Salman, M.Belkhaouda, S.Jodeh, M.Zougagh, $H$. Oudda (2016) Experimental and theoretical investigation of sulfadiazine as a corrosion inhibitor for carbon steel in $\mathrm{HCl}$ medium, Der Pharm. Chem., 8(2), 227-237.

[8] B.EL.Makrini, H.Lgaz, M.Larouj, R.Salghi, A.Rasem Hasan, M.Belkhaouda, S.Jodeh, M.Zougagh, H. Oudda (2016) The inhibition performance of sulfamerazine for corrosion of mild steel in $\mathrm{HCl}$, Der Pharm. Chem., 8(2), 256-268.

[9] I.Batlle, J.Tous (1997) Carob Tree and Ceratonia siliqua Promoting the Conservation and Use of Underutilized and Neglected Crops; Plant Genetic Resources Institute: Rome, p. 92.

[10] F.S. De Souza, C.Giacomelli, R.S.Gonçalves, A.Spinelli (2012) Adsorption behavior of caffeine as agreen corrosion inhibitor for copper, Mater. Sci. Eng., 32(8), 2436-2444.

[11] B.A. Abd-El-Nabey, A.M. Abdel-Gaber, M. El. Said Ali, E.Khamis, S.El-Housseiny (2013) Inhibitive Action of Cannabis Plant Extract on the Corrosion of Copper in $0.5 \mathrm{M} \mathrm{H}_{2} \mathrm{SO}_{4}$, J. Electrochem. Sci., 8, 7124-7137.

[12] O.E.Nnabuk, I.I.Benedict, N.D.Simon, D.P.Elaoyi (2012) Inhibitive and adsorption properties of ethanol extract of Hibiscus sabdariffa calyx for the corrosion of mild steel in $0.1 \mathrm{M} \mathrm{HCl}$, Green Chem. Lett. Rev., 5(1), 45-53.

[13] S.A.Umoren, U.M.Eduok, A.U.Israel, I.B.Obot, M.M.Solomon (2012) Coconut coir dust extract: a novel eco-friendly corrosion inhibitor for $\mathrm{Al}$ in $\mathrm{HCl}$ solutions, Green Chem. Lett. Rev., 5(3), 303-313.

[14] E.I.Ating, S.A.Umoren, I.I.Udousoro, E.E.Ebenso, A.P.Udoh (2010) Leaves extract of Ananas sativum as green corrosion inhibitor for aluminium in 
hydrochloric acid solutions, Green Chem. Lett. Rev., 3(2), 61-68.

[15] S.K.Sharma, M.Ackmez, J.Gargi, S.Jyoti (2010) Corrosion inhibition and adsorption properties of Azadirachtaindica mature leaves extract as green inhibitor for mild steel in $\mathrm{HNO}_{3}$, Green Chem. Lett. Rev., 3(1), 7-15.

[16] Z.V.P.Murthy, K.Vijayaragavan (2014) Mild steel corrosion inhibition by acid extract of leaves of Hibiscus sabdariffa as a green corrosion inhibitor and sorption behavior, Green Chem. Lett. Rev., 7(3), 209-219.

[17] O.E.Nnabuk, A.O.Stevens, N.A.lbiam (2010) Ethanol extract of Ocimumgratissimum as a green corrosion inhibitor for the corrosion of mild steel in $\mathrm{H}_{2} \mathrm{SO}_{4}$, Green Chem. Lett. Rev. 3(3), 165-172.

[18] V.Tackholm (1974) Student flora of Egypt. Published by Cairo Univ. 6, p.568.

[19] A.S.Fouda, M.Morsi, H.A.Mosallam (2016) Capsicum extract as green corrosion extract for carbon steel in hydrochloric acid solutions, Zastita materijala, 57(1), $33-47$.

[20] A.S. Fouda, K. Shalabi, A.M. Nofal, M.A. El-zekred (2018) Methanol Extract of RumexVesicarius L. as Eco-Friendly Corrosion Inhibitor for Carbon Steel in Sulfuric Acid Solution, Chem. Sci. Trans., 7(1), 101-111.

[21] A.S.Fouda, A.Y.El-Khateeb, N.M.Elbahrawi (2017) Cupressus sempervirens extract as green inhibitor for corrosion of carbon steel in hydrochloric acid solutions, Zastita materijala, 58(2),131-145.

[22] A.S.Fouda, E.Abdel Haleemb (2018) Berry Leaves Extract as Green Effective Corrosion Inhibitor for $\mathrm{Cu}$ in Nitric Acid Solutions, Surf. Eng. Appl. Electrochem., 54(5), 498-507.

[23] A.S. Fouda, S.M. Rashwan, M.M.K. Darwish, N.M. Arman, (2018) Corrosion Inhibition of $\mathrm{Zn}$ in a $0.5 \mathrm{M}$ $\mathrm{HCl}$ Solution byAilanthusAltissima Extract, Portugaliae, Electrochim. Acta, 36(5), 309-323.

[24] A.S.Fouda, A.H.Ali (2018) Egy- dronate drug as promising corrosion inhibitor of $\mathrm{C}$ - steel in aqueous medium, Zastita materijala, 59(1), $126-141$.

[25] A.S.Fouda, F.I.El-Dossoki, H.A.El-Nadr, A.ElHussein (2018) Moringa oleifera plant extract as a copper corrosion inhibitor in binary acid mixture $\left(\mathrm{HNO}_{3}+\mathrm{H}_{3} \mathrm{PO}_{4}\right)$, Zastita materijala, 59(3), $422-435$.

[26] A.S.Fouda, G.Y. El-Ewady, H.M. El-Abbasy, S.M. Zidan (2018) Vitex agnus castus plant extract as safe corrosion inhibitor for carbon steel 1018 in $1 \mathrm{M}$ hydrochloric acid, JCBPSC, 8(3) 469-491.

[27] A.S.Fouda, R.M.AbouShahba, A.E.El-Shenawy. T.J.A.Seyam, (2018) Adsorption and Corrosion Inhibition of Cassia Angustifolia (Senna) Fruit Extract on Mild Steel in Hydrochloric Acid Solution, Chem. Sci. Trans., 7(2), 163-180.

[28] A.S.Fouda, R.M.AbouShahba, A.E.El-Shenawy, T.J.A.Seyam (2018) Evaluation of Cleome Droserifolia (Samwah) as Green Corrosion Inhibitor for Mild Steel in $1 \mathrm{M} \mathrm{HCl}$ Solution, Int. J. Electochem. Sci., 13, 7057 - 7075.
[29] A.Ahangarpour, A.A.Oroojan, L.Khorsandi, S.A.Najimi (2017) Pancreatic protective and hypoglycemic effects of Vitex agnus-castus L. fruit hydroalcoholic extract in D-galactose-induced aging mouse model, Res. Pharm. Sci., 12(2), 137-143.

[30] A.Asdadi, A.Hamdouch, A.Oukacha, R.Moutaj, S.Gharby, H.Harhar, M.El Hadek, B.Chebli, L.M. I.Hassani (2015) Study on chemical analysis, antioxidant and in vitro antifungal activities of essential oil from wild Vitex agnus-castus L. seeds growing in area of Argan Tree of Morocco against clinical strains of Candida responsible for nosocomial infections, J. Mycol. Med., 25(4), e118e127.

[31] F.B.El-kassas, A.M.Ali, S.E.Mostafa (2014) Phenolic compounds as antioxidants of some products manufactured from two cultivated Egyptian varieties of seedless grapes, Ann. Agric. Sci., 59(2), 195-9.

[32] P.Mattila, J.Astola, J.Kumpulainen (2000) Determination of flavonoids in plant material by HPLC with diode-array and electro-array detections, J. Agric. Food Chem., 48(12), 5834-41.

[33] P.Goupy, M.Hugues, P.Boivin, M.JosèpheAmiot (1999) Antioxidant composition and activity of barley (Hordeum vulgare) and malt extracts and ofisolated phenolic compounds, Sci. food Agric., 79(12), 1625-34.

[34] A.H.Hanafy Ahmed, A.R.M.Ghalab, O.S.Hussein A.M.El-Hefny (2011) Effect of Gamma Rays and Salinity on Growth and Chemical Composition of Ambrosia maritima L. Plants, J. Radiat. Res. Appl., Sci. 4(4A), 1139-1162.

[35] M.E.I.Badawy, S.A.M.Abdelgaleil, T.Suganuma M. Fuji (2014) Antibacterial and biochemical activity of pseudoguaianolide sesquiterpenes isolated from Ambrosia maritima against plant pathogenic bacteria, Plant Protect., Sci. 50(2), 64-69.

[36] M.Saeed, S.Jacob, L.P.Sandjo, Y.Sugimoto, H.E. Khalid, T.Opatz, E.Thines, T.Efferth (2015) Cytotoxicity of the sesquiterpene lactones neoambrosin and damsin from Ambrosia maritima against multidrug-resistant cancer cells, Front. Pharmacol., 6, 267-275.

[37] A.S.Fouda, G.Y.El-Ewady, H.M.El-Abbasy, S.M.Zidan (2018) Vitex agnus castus plant extract as Safe corrosion inhibitor for carbon steel 1018 in $1 \mathrm{M}$ hydrochloric acid, J. Chem. Biol. Phys. Sci., 8(3), 469-491.

[38] A.S.Fouda, M.Abdallah, S.A.Shama, E.A.Afifi (2008) Azodyes as corrosion inhibitors for dissolution of c-steel in hydrochloric acid solution, AFR. J. Pure Appl. Chem., 2(9), 083-091.

[39] S.K.Saha, A.Dutta, P.Ghosh, D.Sukul, P.Banerjee (2016) Novel Schiff-base molecules as efficient corrosion inhibitors for mild steel surface in $1 \mathrm{M} \mathrm{HCl}$ medium experimental and theoretical approach, Phys. Chem. Chem. Phys., 18(27), 17898-17911.

[40] M.N. El-Haddad (2013 Chitosan as a green inhibitor for copper corrosion in acidic medium, Int. J. Biol. Macromol., 55, 142-149. 
[41] A.S.Fouda, A.Y.El-Khateeb, I.Mousa, M.Fakih (2015) Adhatoda aqueous plant extract as environmentally benign corrosion inhibitor for carbon steel in sanitation water in polluted $\mathrm{NaCl}$ solutions and its biological effect on bacteria, Nat. Sci., 13, 71-82.

[42] K.Shalabi, Y.M.Abdallah, H.M.Hassan, A.S.Fouda (2014) Adsorption and corrosion inhibition of Atropa belladonna extract on carbon steel in $1 \mathrm{M} \mathrm{HCl}$ solution, Int. J. Electrochem. Sci, 9(3), 1468 - 1487.

[43] M.Eeva, J.P.Salo, K.M.Oksman-Caldentey (1998) Determination of the main tropane alkaloids from transformed Hyoscyamusmuticus plants by capillary zone electrophoresis, J. Pharm. Biomed. Anal. 16(5), 717-722.

[44] G.M.Schmid, H.J.Huang (1980) Spectroelectrochemical studies of the inhibition effect of 4,7-diphenyl -1,10-phenanthroline on the corrosion of 304 stainless steel, Corros. Sci., 20(8-9), 10411057.

[45] A.Y.El-Etre (2007) Inhibition of acid corrosion of carbon steel using aqueous extract of olive leaves, J. Colloid. Interface Sc. 314(2), 578-583.

[46] A.S.Fouda, K.Shalabi, A. E-Hossiany (2016) Moxifloxacin antibiotic as green corrosion inhibitor for carbon steel in $1 \mathrm{M} \mathrm{HCl}$, Journal of Bio-and Tribo-Corrosion, 2(3), 1-13.

[47] R.Kamaraj, P.Ganesan, J.Lakshmi, S.Vasudevan (2013) Removal of copper from water by electrocoagulation process--effect of alternating current (AC) and direct current (DC), Environ. Sci.Pollut. Res. Int., 20(1), 399-412.

[48] E.E.Ebenso, I.B.Obot (2010) Inhibitive properties, thermodynamic characterization and quantum chemical studies of secnidazole on mild steel corrosion in acidic medium, Int. J. Electrochem.Sci., 5(12), 2012-2035

[49] F.Bentiss, M.Traisnel, N.Chaibi, B.Mernari, H.Vezin, M.Lagrenee (2002) 2,5-Bis(n-methoxyphenyl)-1,3,4oxadiazoles used as corrosion inhibitors in acidic media: correlation between inhibition efficiency and chemical structure, Corr.Sci., 44(10), 2271-2289.

[50] A.S.Fouda, K.Shalabi, A.A.Nazeer (2015) Corrosion inhibition of carbon steel by Roselle extract in hydrochloric acid solution: electrochemical and surface study, Res. Chem.Intermed., 41(7), 48334850.

[51] M.Bouklah, N.Benchat, B.Hammouti, A.Aouniti, S.Kertit (2006) Thermodynamic characterisation of steel corrosion and inhibitor adsorption of pyridazine compounds in $0.5 \mathrm{M} \mathrm{H} 2 \mathrm{SO} 4$. Mater. Lett., 60, 1901 1905.

[52] [52] K.O.Orubite, N.C.Oforka (2004) Inhibition of the corrosion of mild steel in hydrochloric acid solutions by the extracts of leaves of NypafruticansWurmb., Mater. Lett., 58, 1768-1772.

[53] M.Hazwan Hussin, M.Jain Kassim (2011) The corrosion inhibition and adsorption behavior of Uncariagambir extract on mild steel in $1 \mathrm{M} \mathrm{HCl}$., Mater. Chem. Phys., 125, 461-468.
[54] V. Ramesh Saliyan, A.V.Adhikari (2007) Inhibition of corrosion of mild steel in acid media by N'benzylidene-3-(quinolin-4-ylthio) propanohydrazide., Bull. Mater. Sci., 31, 699-711.

[55] Y. Yan, W. Li, L. Cai, B.Hou (2008) Electrochemical and quantum chemical study of purines as corrosion inhibitors for mild steel in $1 \mathrm{M} \mathrm{HCl}$ solution, Electrochim. Acta, 53(20), 5953-5960.

[56] A. Prithiba (2015) Corrosion monitoring of metal Mild steel Aluminium $1 \mathrm{M} \mathrm{HCl}$ interface in the presence of Spathodea campanulata Tecomacapensis leaf and flower extracts Chemical Electrochemical and Theoretical studies, Shodhganga, p.200.

[57] M.Prabakaran, S.H.Kim, V.Hemapriya, I.M.Chung (2016) Evaluation of polyphenol composition and anti-corrosion properties of Cryptostegia grandiflora plant extract on mild steel in acidic medium, J. Indust. Eng. Chem., 37, 47-56.

[58] J.R.Macdonald, W.B. Johanson (1987) Theory in Impedance Spectroscopy, J.R. Macdonald (Ed.), John Wiley\& Sons, New York.

[59] S.F.Mertens, C.Xhoffer, B.C.Decooman, E.Temmerman (1997) Short-Term Deterioration of Polymer-Coated $55 \% \mathrm{Al}-\mathrm{Zn}$ - Part 1: Behavior of Thin Polymer Films, Corrosion. 53 (5), 381-388.

[60] M.Lagrenee, B.Mernari, M.Bouanis, M.Traisnel, F.Bentiss (2002) Study of the mechanism and inhibiting efficiency of 3,5-bis(4-methylthiophenyl)$4 \mathrm{H}-1,2,4$-triazole on mild steel corrosion in acidic media, Corr. Sci., 44(3), 573-588.

[61] E.McCafferty, N.Hackerman (1972) Double Layer Capacitance of Iron and Corrosion Inhibition with Polymethylene Diamines, J.Electrochem. Soc.,119(2), 146-154.

[62] S.S.Abdel-Rehim, K.F.Khaled, N.S.Abd-Elshafi (2006) Electrochemical frequency modulation as a new technique for monitoring corrosion inhibition of iron in acid media by new thiourea derivative, Electrochim. Acta., 51(16), 3269-3277.

[63] R.W.Bosch, J.Hubrecht, W.F.Bogaerts B.C.Syrett (2001) Electrochemical Frequency Modulation: A New Electrochemical Technique for Online Corrosion Monitoring, Corrosion, 57(1), 60-70.

[64] Y.M.Abdallah, H.M.Hassan, K.Shalabi, A.S.Fouda (2014) EOffects of Arctostaphylos uva-ursi Extract as Green Corrosion Inhibitor for Cu10Ni Alloy in $1 \mathrm{M}$ HNO3p, Int. J. Electrochem. Sci., 9, 5073-5091.

[65] A.S.Fouda, K.Shalabi, G.Y.Elewady, H.F.Merayyed (2014) COhalcone derivatives as corrosion inhibitors for carbon steel in $1 \mathrm{M} \mathrm{HCl}$ solutions, Int. J. Electrochem. Sci., 9, 7038-7058.

[66] A.A.Al-Amiery, F.A.B.Kassim, A.A.H.Kadhum, A.B.Mohamad (2016) Synthesis and characterization of a novel eco-friendly corrosion inhibition for mild steel in $1 \mathrm{M}$ hydrochloric acid, Sci. Rep., 6: 19890

[67] V. D'Antò, R.Rongo, G.Ametrano, G.Spagnuolo, P.Manzo, R.Martina, S.Paduano, R.Valletta (2012) Evaluation of surface roughness of orthodontic 
wires by means of atomic force microscopy, Angle Orthod., 82(5), 922-928.

[68] H.Aghajani, M.S.Motlagh (2017) Effect of temperature on surface characteristics of nitrogen ion implanted biocompatible titanium, J. Mater. Sci. Mater. Med., 28(2), 29.
[69] A.F.Gualdrón, E.N.Becerra, D.Y.Peña, J.C. Gutiérrez, H.Q. Becerra (2013) Inhibitory effect of Eucalyptus and Lippia Alba essential oils on the corrosion of mild steel in hydrochloric acid, J. Mater. Environ. Sci., 4 (1), 143-158.

\section{IZVOD}

\section{INHIBITORNO PONAŠANJE EKSTRAKTA AMBROSIA MARITIMA KAO INHIBITORA KOROZIJE ZA UGLJENIČNI ČELIK U 1M HCI}

Ispitivan je efekat inhibicije Ambrosia Maritima, koji je, takođe, dobio ime po Damssisa ekstraktu, prema koroziji ugljeničnog čelika u $1 \mathrm{M}$ rastvoru $\mathrm{HCl}$, koristeći metodu potenciodinamičke polarizacije, elektrohemijsku impedansnu spektroskopiju (EIS) i metodu EFM. Proces adsorpcije prati Langmirovu adsorpcionu izotermu. Nađeno je da ekstrakt deluje kao mešani tip inhibitora $u$ $1 \mathrm{M} \mathrm{HCl}$. Proračunati adsorpcioni termodinamički parametri pokazali su da je adsorpcija spontani, endotermni proces praćen povećanjem entropije. Maksimalna vrednost inhibicije dostigla je 92,6\% u prisustvu ekstrakta od 300 ppm, korišćenjem Tafelove polarizacione krive. Rezultati dobijeni iz različitih elektrohemijskih postupaka bili su u velikoj saglasnosti. Pretpostavlja se da se inhibicija ekstrakta odvija kroz adsorpciju aktivnih sastojaka na površini metala. Morfologija površine analizirana je pomoću skenirajuće elektronske mikroskopije (SEM), FTIR i atomske mikroskopije (AFM), koja je potvrdila prisustvo zaštitnog filma ekstraktnog molekula na površini ugljeničnog čelika 1018.

Ključne reči: Ambrosia Maritima, Damssisa, ugljenični čelik 1018, HCl, AFM, SEM.

Naučni rad

Rad primljen: 08. 12. 2018.

Rad prihvaćen: 12. 01. 2019.

Rad je dostupan na sajtu: www.idk.org.rs/casopis

(c) 2019 Authors. Published by Engineering Society for Corrosion. This article is an open access article distributed under the terms and conditions of the Creative Commons Attribution 4.0 International license (https://creativecommons.org/licenses/by/4.0/) 